\title{
Heterogeneous Electro-Fenton as "Green" Technology for Pharmaceutical Removal: A Review
}

\author{
Jessica Meijide ${ }^{1,2, *(\mathbb{D})}$, Patrick S. M. Dunlop ${ }^{2}$, Marta Pazos $^{1}$ (D) and María Angeles Sanromán ${ }^{1(\mathbb{D})}$ \\ 1 CINTECX, Grupo de Bioingeniería y Procesos Sostenibles, Departamento de Ingeniería Química, \\ Campus Lagoas-Marcosende, University of Vigo, 36310 Vigo, Spain; mcurras@uvigo.es (M.P.); \\ sanroman@uvigo.es (M.A.S.) \\ 2 Nanotechnology and Integrated BioEngineering Centre, School of Engineering, University of Ulster, \\ Newtownabbey BT37 0QB, UK; psm.dunlop@ulster.ac.uk \\ * Correspondence: jmeijide@uvigo.es
}

Citation: Meijide, J.; Dunlop, P.S.M.;

Pazos, M.; Sanromán, M.A.

Heterogeneous Electro-Fenton as

"Green" Technology for

Pharmaceutical Removal: A Review.

Catalysts 2021, 11, 85. https://

doi.org/10.3390/catal11010085

Received: 16 December 2020

Accepted: 6 January 2021

Published: 9 January 2021

Publisher's Note: MDPI stays neutral with regard to jurisdictional clai$\mathrm{ms}$ in published maps and institutional affiliations.

Copyright: $(2021$ by the authors. Licensee MDPI, Basel, Switzerland. This article is an open access article distributed under the terms and conditions of the Creative Commons Attribution (CC BY) license (https:// creativecommons.org/licenses/by/ $4.0 /)$
Abstract: The presence of pharmaceutical products in the water cycle may cause harmful effects such as morphological, metabolic and sex alterations in aquatic organisms and the selection/development of organisms resistant to antimicrobial agents. The compounds' stability and persistent character hinder their elimination by conventional physico-chemical and biological treatments and thus, the development of new water purification technologies has drawn great attention from academic and industrial researchers. Recently, the electro-Fenton process has been demonstrated to be a viable alternative for the removal of these hazardous, recalcitrant compounds. This process occurs under the action of a suitable catalyst, with the majority of current scientific research focused on heterogeneous systems. A significant area of research centres working on the development of an appropriate catalyst able to overcome the operating limitations associated with the homogeneous process is concerned with the short service life and difficulty in the separation/recovery of the catalyst from polluted water. This review highlights a present trend in the use of different materials as electro-Fenton catalysts for pharmaceutical compound removal from aquatic environments. The main challenges facing these technologies revolve around the enhancement of performance, stability for long-term use, life-cycle analysis considerations and cost-effectiveness. Although treatment efficiency has improved significantly, ongoing research efforts need to deliver economic viability at a larger scale due to the high operating costs, primarily related to energy consumption.

Keywords: electro-Fenton; heterogeneous catalyst; pharmaceuticals; aqueous solution

\section{Introduction}

Anthropogenic activities are considered a significant threat to the ecological environment with unsustainable development practices leading to deterioration in the surface water resource quality and as such, contamination issues for drinking water supply [1]. Therefore, growing awareness of environmental concerns has prompted the introduction of new legislation in order to preserve the environment and natural resources. The 2030 Agenda for Sustainable Development Goals, approved by all United Nations Member States in 2015, includes a specific aim focusing on the provision of safe and clean drinking water-with the protection of water sources a critical component [2].

More than 700 emerging pollutants and their derivatives have been detected in the European aquatic environment [3]. These included heavy metals and biological contaminants, as well as synthetic organic pollutants and emerging pollutants such as pharmaceuticals (both prescription and over-the-counter drugs), personal care products, flame retardants, cationic surfactants, life-style products (caffeine and nicotine), industrial additives and agrochemicals.

The range of pharmaceutical products may be classified into antibiotics, nonsteroidal anti-inflammatory drugs (NSAIDs), $\beta$-blockers, contrast agents, anticonvulsants, hormones 
and lipid regulators [4], with antibiotics and NSAIDs most commonly reported as water pollutants due to their high use for clinical purposes (Table 1) [5]. The increasing demand for new drugs has resulted in more than 3000 pharmaceuticals being produced, with new chemical and biologically active molecules being released into the environment. Pharmaceutical products have been detected in many aqueous resources such as surface water, wastewater and even drinking water at concentrations ranging up to $10 \mu \mathrm{g} / \mathrm{L}$ [4]. The primary route of entry to the environment is from effluents generated on pharmaceuticals industries, hospitals and houses (containing both parent compound and metabolites excreted by animals and humans) with a minor contribution from the inappropriate disposal of expired drugs [6]. In addition, urban runoff and leaching from agricultural land contribute to the flow of drugs into the groundwater streams [7]. Given the potential harmful effects of these emerging pollutants, European Directives 2015/495/EU and 2018/840/EU include antibiotics such as amoxicillin and ciprofloxacin requiring testing to monitor their occurrence, distribution, frequency and inclusion in risk assessment.

The main methods widely used for the removal of pharmaceutical products in conventional sewage treatment plants include biotransformation/biodegradation and/or adsorption on classical adsorbents (e.g., activated carbon) [9]. Previous studies have considered wastewater treatment plants (WWTPs) as the main gateways for the release of emerging pollutants into aquatic environments, e.g., Carballa et al. [10] reported around 70\% ibuprofen removal by conventional biological treatments in municipal WWTPs, however, classical WWTPs are not specifically designed to remove recalcitrant, low level pharmaceuticals.

Advanced oxidation processes (AOPs) have been considered as a suitable range of technologies to reduce concentration levels and toxicity associated with the pharma compound-where they are able to deal with the complex stable structures. In particular, electrochemical advanced oxidation processes such as the electro-Fenton process are regarded as an eco-friendly approach based on the formation of strong oxidants with potential to degrade and mineralise organic pollutants.

In the electro-Fenton process, the in situ electrogeneration of hydrogen peroxide under acidic $\mathrm{pH}$ via oxygen reduction (Equation (1)), minimises the operating costs through the avoidance of the continuous addition of hydrogen peroxide to the bulk solution (as is common in the standard Fenton process). The generated hydrogen peroxide reacts with ferrous ion resulting in the production of hydroxyl radicals and ferric ions through Fenton's reaction (Equation (2)). Simultaneously, the continuous regeneration of ferrous ions from ferric ions occurs on the cathode (Equation (3)) ensuring an adequate catalytic concentration in the aqueous phase, with the associated reduction in free radical scavenging (Equation (4)):

$$
\begin{gathered}
\mathrm{O}_{2}+2 \mathrm{H}^{+}+2 \mathrm{e}^{-} \rightarrow \mathrm{H}_{2} \mathrm{O}_{2} \\
\mathrm{Fe}^{2+}+\mathrm{H}_{2} \mathrm{O}_{2}+\mathrm{H}^{+} \rightarrow \mathrm{Fe}^{3+}+\mathrm{H}_{2} \mathrm{O}+\bullet{ }^{\bullet} \mathrm{H} \\
\mathrm{Fe}^{3+}+\mathrm{e}^{-} \rightarrow \mathrm{Fe}^{2+} \\
\mathrm{Fe}^{2+}+{ }^{\bullet} \mathrm{OH} \rightarrow \mathrm{Fe}^{3+}+\mathrm{OH}^{-}
\end{gathered}
$$

Furthermore, water molecules in the bulk solution may be oxidised to oxygen at the anode subsequently generating additional hydrogen peroxide (via Equation (5)). By using anode materials with high over potential such as platinum and boron-doped diamond (BDD), hydroxyl radicals may be formed on the anodes surface according to Equation (6) [11]:

$$
\begin{gathered}
\mathrm{H}_{2} \mathrm{O} \rightarrow \frac{1}{2} \mathrm{O}_{2}+2 \mathrm{H}^{+}+2 \mathrm{e}^{-} \\
\mathrm{H}_{2} \mathrm{O} \rightarrow \cdot \cdot \mathrm{OH}+\mathrm{H}^{+}+\mathrm{e}^{-}
\end{gathered}
$$


Table 1. List of common pharmaceuticals mineralised by electro-Fenton processes.

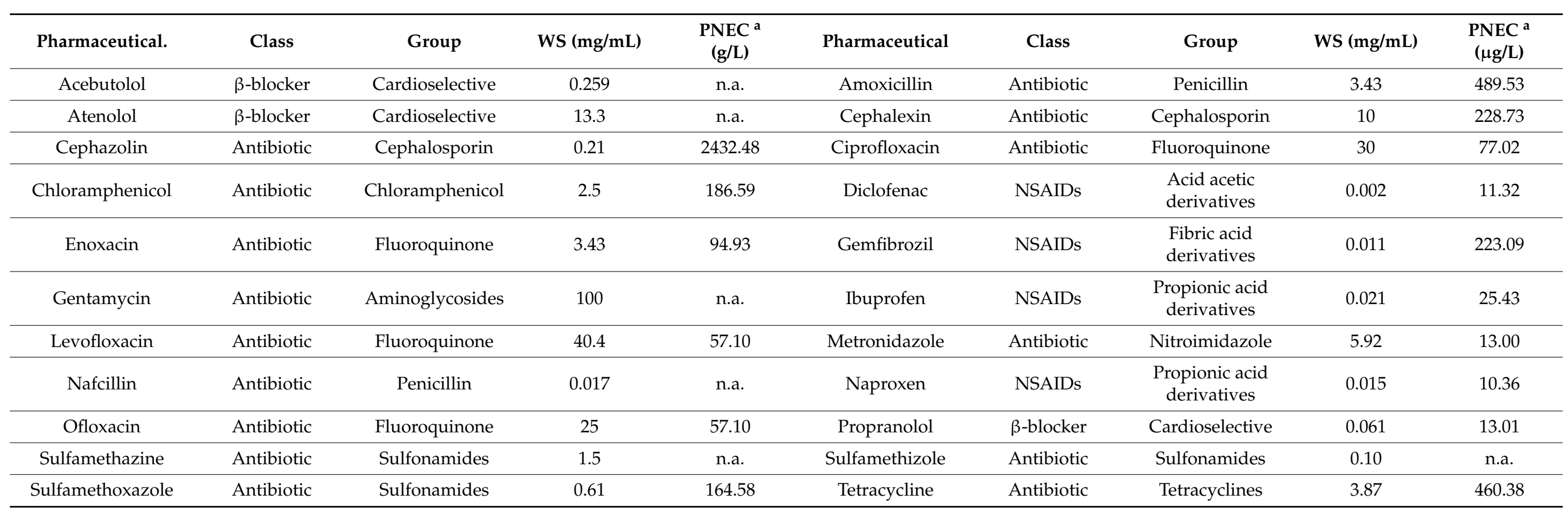

NSAIDs: nonsteroidal anti-inflammatory drugs, WS: water solubility (values obtained from PubChem ${ }^{\circledR}$ database), PNEC: predicted no-effect concentrations using Daphnia Magna model ( $\mu$ g/L). ${ }^{\text {[ }}$ [8]. 
According to the literature, the electro-Fenton mechanism depends considerably on the solution $\mathrm{pH}$ [12]. Under acidic conditions $(\mathrm{pH}<4.5)$, the limiting step in the electroFenton process corresponds to the iron redox cycle, determined by the solubility of the catalyst. $\mathrm{H}_{2} \mathrm{O}_{2}$ activation by the dissolved iron source at neutral and alkaline conditions is negligible and thus, maintaining a soluble catalyst determines the production rate of hydroxyl radicals.

Despite research demonstrating high removal and mineralisation percentages with a wide range of pharmaceutical target pollutants, the electro-Fenton process suffers from multiple operational limitations, mainly attributed to the homogeneous process. These include a narrow working $\mathrm{pH}$, difficult catalyst reusability and additional pollution by soluble salts in the effluent.

To advance the field and develop industrially scalable technology, the search of new heterogeneous catalysts applied to electro-Fenton processes has gained attention from the scientific research community with a considerable number of Scopus@indexed scientific publications over recent years. The number of relevant articles, reviews, report, data studies and books including the keyword "heterogeneous catalyst" related to water purification using electro-Fenton process has increased exponentially over the past 5 years (Figure 1a), with research on antibiotic removal gaining more interest than the other classes of pharmaceutical compounds (Figure 1b).

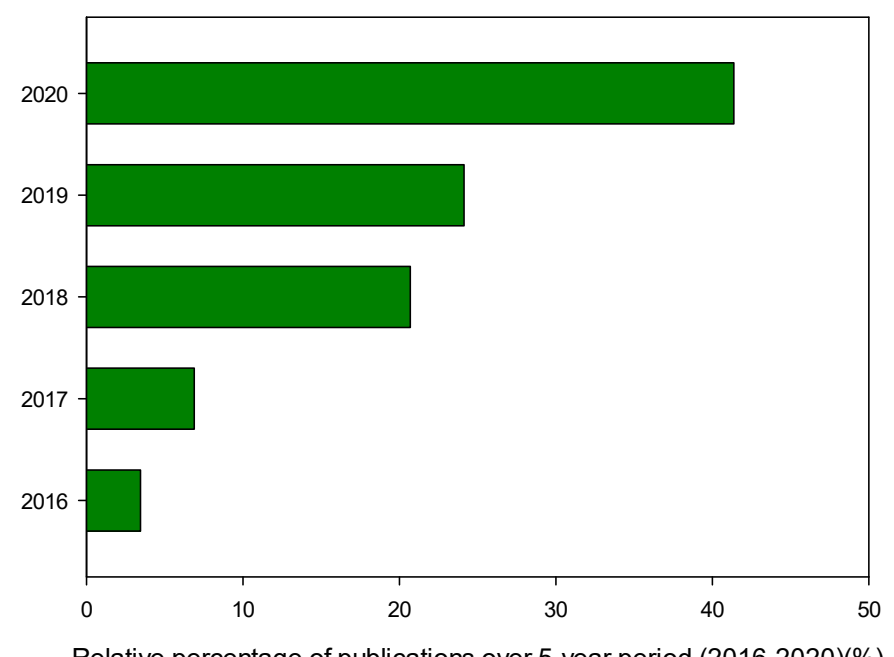

(A)

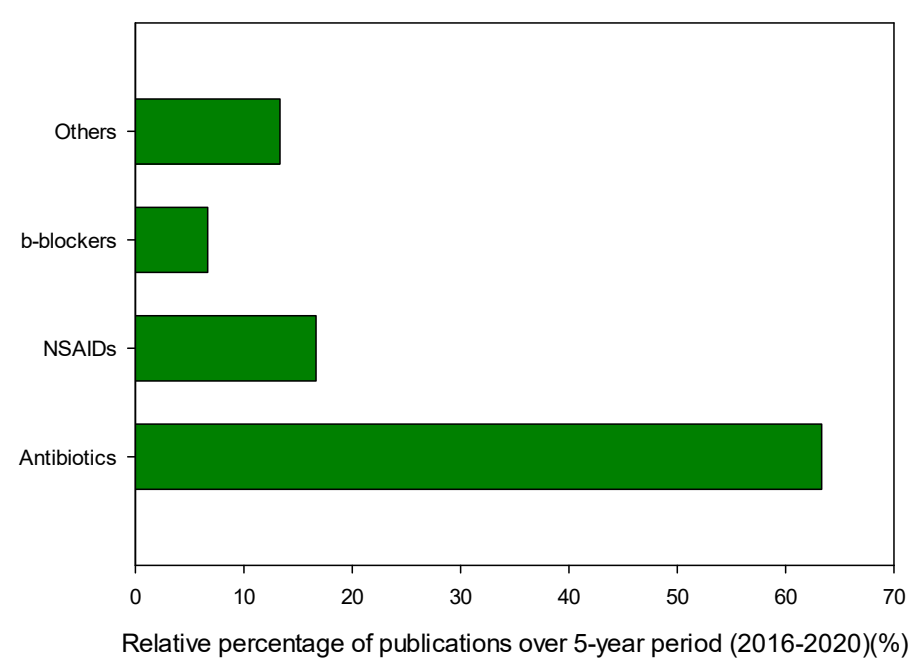

(B)

Figure 1. Relative percentage (\%) of the total heterogeneous electro-Fenton process publications over the 5-year period (2016-2020) for pharmaceutical removal from the aqueous phase as a function of the published year (A) and class of pharmaceuticals (B) (Source: Scopus $\left.{ }^{\circledR}\right)$.

The research reported in this review article specifically covers this period of intense growth (2016-2020), focusing on pharmaceutical removal by heterogeneous electro-Fenton process. The basic fundamentals and characteristics of heterogeneous electro-Fenton process have been described to aid in the understand of the key role played by reactive oxygen species produced by the process. Furthermore, an analysis of critical process parameters underpinning heterogeneous catalysts for pharmaceutical removal has been detailed. Finally, the case study example is included, detailing the application of heterogeneous electro-Fenton process for the removal of common pharmaceuticals from aqueous solution.

\section{Fundamentals of Heterogeneous Electro-Fenton Process}

To date, the Haber-Weiss cycle mechanism has been considered the primary reaction mechanism for heterogeneous electro-Fenton process [12]. Hydroxyl radical generation on the catalyst surface begins by the interaction of $\mathrm{H}_{2} \mathrm{O}_{2}$ and iron species such as $\equiv \mathrm{Fe}^{\mathrm{III}}-\mathrm{OH}$ and $\equiv \mathrm{Fe}^{\mathrm{II}}-\mathrm{OH}$ (Equation (7)) resulting in a $\equiv \mathrm{Fe}^{\mathrm{III}}-\mathrm{OH}\left(\mathrm{H}_{2} \mathrm{O}_{2}\right)_{(\mathrm{s})}$ formation (Equation (8)) 
at the cathode. This complex may be subjected to reversible ground-state electron transfer (Equation (9)) and further deactivation (Equation (10)) to generate $\equiv \mathrm{Fe}^{\mathrm{II}}-\mathrm{OH}$ and $\mathrm{HO}_{2} \bullet$. Subsequently, $\equiv \mathrm{Fe}^{\mathrm{II}}-\mathrm{OH}$ catalyses $\mathrm{H}_{2} \mathrm{O}_{2}$ decomposition to form hydroxyl radicals (Equation (11)) which subsequently attack pollutant species, theoretically resulting in the complete mineralisation of the parent compound and intermediates to $\mathrm{CO}_{2}$ and $\mathrm{H}_{2} \mathrm{O}[12,13]$ :

$$
\begin{aligned}
& \equiv \mathrm{Fe}^{\mathrm{III}}-\mathrm{OH}+\mathrm{e}^{-} \rightarrow \equiv \mathrm{Fe}{ }^{\mathrm{II}}-\mathrm{OH} \\
& \equiv \mathrm{Fe}^{\mathrm{III}}-\mathrm{OH}+\mathrm{H}_{2} \mathrm{O}_{2} \rightarrow \equiv \mathrm{Fe}^{\mathrm{III}}-\mathrm{OH}\left(\mathrm{H}_{2} \mathrm{O}_{2}\right)_{(\mathrm{s})} \\
& \equiv \mathrm{Fe}^{\mathrm{III}}-\mathrm{OH}\left(\mathrm{H}_{2} \mathrm{O}_{2}\right)_{(\mathrm{s})} \rightarrow \equiv \mathrm{Fe}^{\mathrm{II}}-\mathrm{OH}\left(\mathrm{HO}_{2}\right)_{(\mathrm{s})}+\mathrm{H}^{+} \\
& \equiv \mathrm{Fe}^{\mathrm{II}}-\mathrm{OH}\left(\mathrm{HO}_{2}{ }^{\bullet}\right)_{(\mathrm{s})} \rightarrow \equiv \mathrm{Fe}^{\mathrm{II}}-\mathrm{OH}+\mathrm{HO}_{2}^{\bullet}+\mathrm{H}^{+} \\
& \equiv \mathrm{Fe}^{\mathrm{II}}-\mathrm{OH}+\mathrm{H}_{2} \mathrm{O}_{2} \rightarrow \equiv \mathrm{Fe}^{\mathrm{III}}-\mathrm{OH}+{ }^{\bullet} \mathrm{OH}+\mathrm{OH}^{-}
\end{aligned}
$$

Nowadays, metal sulphides $\left(\mathrm{MoS}_{2}, \mathrm{WS}_{2}, \mathrm{Cr}_{2} \mathrm{~S}_{3}, \mathrm{CoS}_{2}, \mathrm{PbS}\right.$ or $\left.\mathrm{ZnS}\right)$ are widely used as excellent co-catalysts to enhance hydroxyl radical production. The unsaturated sulphur atoms on the metal sulphides surface can capture protons to generate $\mathrm{H}_{2} \mathrm{~S}$ and release metallic active sites with reductive properties. Thus, co-catalysts facilitate the continuous production of $\equiv \mathrm{Fe}^{\mathrm{II}}-\mathrm{OH}$ and hydroxyl radical generation (Equations (12)-(17)) [14]:

$$
\begin{gathered}
\equiv \mathrm{Co}^{\mathrm{II}}-\mathrm{OH}+\equiv \mathrm{Fe}^{\mathrm{III}}-\mathrm{OH} \rightarrow \equiv \mathrm{Co}^{\mathrm{III}}-\mathrm{OH}+\equiv \mathrm{Fe}^{\mathrm{II}}-\mathrm{OH} \\
\equiv \mathrm{Cu}^{\mathrm{I}}-\mathrm{OH}+\equiv \mathrm{Fe}^{\mathrm{III}}-\mathrm{OH} \rightarrow \equiv \mathrm{Cu}^{\mathrm{II}}-\mathrm{OH}+\equiv \mathrm{Fe}^{\mathrm{II}}-\mathrm{OH} \\
\equiv \mathrm{Mo}^{\mathrm{IV}}-\mathrm{OH}+\equiv \mathrm{Fe}^{\mathrm{III}}-\mathrm{OH} \rightarrow \equiv \mathrm{Mo}^{\mathrm{VI}}-\mathrm{OH}+\equiv \mathrm{Fe}^{\mathrm{II}}-\mathrm{OH} \\
\equiv \mathrm{Co}^{\mathrm{II}}-\mathrm{OH}+\mathrm{H}_{2} \mathrm{O}_{2} \rightarrow \equiv \mathrm{Co}^{\mathrm{III}}-\mathrm{OH}++{ }^{\bullet} \mathrm{OH}+\mathrm{OH}^{-} \\
\equiv \mathrm{Cu}^{\mathrm{I}}-\mathrm{OH}+\mathrm{H}_{2} \mathrm{O}_{2} \rightarrow \equiv \mathrm{Cu}^{\mathrm{II}}-\mathrm{OH}++{ }^{\bullet} \mathrm{OH}+\mathrm{OH}^{-} \\
\equiv \mathrm{Mo}^{\mathrm{VI}}-\mathrm{OH}+\mathrm{H}_{2} \mathrm{O}_{2} \rightarrow \equiv \mathrm{Mo}^{\mathrm{IV}}-\mathrm{OH}++{ }^{\bullet} \mathrm{OH}+\mathrm{OH}^{-}
\end{gathered}
$$

\section{Experimental Variables and Parameters of Heterogeneous Electro-Fenton Process}

The performance of the electro-Fenton process depends on the several experimental variables such as cell configuration, electrodes material, solution $\mathrm{pH}$, air flow (oxygen supply), and both catalyst and pollutant concentrations. Of these experimental variables, catalyst concentration, applied current density and $\mathrm{pH}$ have received the most attention with optimisation reaching maximum efficiency in terms of the chemical oxygen demand (COD) and total organic carbon (TOC) removal. However, relevant parameters related to oxidation efficiency and energy consumption must also be analysed to evaluate the electroFenton process performance. To this end, multiple iterative electro-Fenton experimental runs are often carried out by varying exclusively one influencing variable. In general, concentration-time profiles are produced, which exhibit exponential decay with increased treatment with rate constants generated via pseudo-first order kinetics.

\subsection{Effect of Catalyst Concentration}

The degradation rate classically increases as a function of catalyst loading reaching a plateau; however, additional catalyst concentration creates the negative effects decreasing removal efficiency. This is likely due to the presence of scavenging reactions between hydroxyl radicals and an excess of iron released into the bulk solution (Equations (18) and (19)) [15,16]:

$$
\begin{gathered}
\mathrm{Fe}^{2+}+{ }^{\bullet} \mathrm{OH} \rightarrow \mathrm{Fe}^{3+}+\mathrm{OH}^{-} \\
\cdot \mathrm{OH}+\mathrm{H}_{2} \mathrm{O}_{2} \rightarrow \mathrm{H}_{2} \mathrm{O}+\mathrm{HO}_{2}{ }^{-}
\end{gathered}
$$

Furthermore, the inclusion of excessive catalyst promotes aggregation within the bulk solution which results in a decrease in catalyst active surface area and an associated reduction in degradation [15]. 


\subsection{Influence of Applied Current Intensity}

Applied current intensity has been considered responsible for the regulation of hydroxyl radical generation (Equations (1) and (3)), and $\mathrm{M}(\mathrm{OH})$ production (Equation (7)) [17] At low current densities, $\mathrm{H}_{2} \mathrm{O}_{2}$ electrogeneration takes place under conditions of controlled electron transfer. Therefore, increasing the current enhances charge distribution through the cathode, leading to an increase in hydroxyl radical concentration within the solution. Nevertheless, the excessive current can promote side reactions such as $\mathrm{H}_{2} \mathrm{O}_{2}$ decomposition (Equation (20)) and a reduction of as-generated protons to hydrogen gas (Equation (21)) [15,18]:

$$
\begin{gathered}
\mathrm{H}_{2} \mathrm{O}_{2}+2 \mathrm{H}^{+}+2 \mathrm{e}^{-} \rightarrow 2 \mathrm{H}_{2} \mathrm{O}, \mathrm{E}_{0}=1.77 \mathrm{~V} \text { vs. SHE } \\
2 \mathrm{H}^{+}+2 \mathrm{e}^{-} \rightarrow 2 \mathrm{H}_{2}, \mathrm{E}_{0}=0 \mathrm{~V}
\end{gathered}
$$

\subsection{Solution $p H$ Effect}

$\mathrm{pH}$ of the solution represents a key role in the degradation and subsequent mineralisation of organic pollutants via heterogenous electro-Fenton process in the presence of solid catalysts [19], primarily due to catalyst surface charge and dissolution characteristics. The use of a heterogeneous catalyst allows operation at circumneutral and alkaline conditions with slow degradation efficiency noted over $\mathrm{pH} 4.5$ as a result of the $\mathrm{H}_{2} \mathrm{O}_{2}$ decomposition into $\mathrm{H}_{2} \mathrm{O}$ and $\mathrm{O}_{2}$ [16]. $\mathrm{pH}$ variations have been associated with the continuous hydrolysis of catalyst ions such as iron and copper, leading to enhanced pollutant removal mediated by free radicals oxidation [20].

\subsection{Oxidation Efficiency and Energy Consumption}

From total organic carbon (TOC) measurements, mineralisation current efficiency (MCE) for an electrolysed solution may be estimated using Equation (22)) [21]:

$$
\operatorname{MCE}(\%)=\left(\mathrm{n} \times \mathrm{F} \times \Delta(\text { TOC })_{\exp }\right) /\left(4.32 \times 10^{7} \times \mathrm{m} \times \mathrm{I} \times \mathrm{t}\right)
$$

where $\mathrm{n}$ is the number of electrons consumed per molecule mineralised, $\mathrm{F}$ is Faraday's constant $(96,500 \mathrm{C} / \mathrm{mol}), \mathrm{V}$ is the volume $(\mathrm{L}), \Delta(\mathrm{TOC})_{\exp }$ is the experimental TOC decay $(\mathrm{mg} / \mathrm{L}), 4.32 \times 10^{7}$ a conversion factor, $\mathrm{m}$ is the number of carbon atoms within the molecule and I is the applied total current (A). The number of electrons (n) exchanged per each pollutant molecule is estimated as a function of total mineralisation to carbon dioxide and inorganic ions.

Electrical energy consumption has been considered as the main operational cost for electrochemical technologies [22,23]. When operating at a constant applied current, the energy consumption per unit volume (EC) and unit TOC mass $\left(\mathrm{EC}_{\mathrm{TOC}}\right)$ are calculated as described in Equations (23) and (24), respectively:

$$
\begin{gathered}
\mathrm{E}_{\mathrm{C}}\left(\mathrm{kWh} / \mathrm{m}^{3}\right)=\left(\mathrm{E}_{\text {cell }} \times \mathrm{I} \times \mathrm{t}\right) / \mathrm{V} \\
\mathrm{E}_{\mathrm{TOC}}\left(\mathrm{kWh} / \mathrm{g}_{\mathrm{TOC}}\right)=\left(\mathrm{E}_{\text {cell }} \times \mathrm{I} \times \mathrm{t}\right) /\left(\Delta(\mathrm{TOC})_{\exp } \times \mathrm{V}\right)
\end{gathered}
$$

where $\mathrm{E}_{\text {cell }}$ is the average potential difference $(\mathrm{V}), \mathrm{I}$ is the applied current intensity $(\mathrm{A}), \mathrm{V}$ the volume $(\mathrm{L}), \mathrm{t}$ the electrolysis time $(\mathrm{h})$ and $\Delta(\mathrm{TOC})_{\text {exp }}$ the experimental TOC decay $(\mathrm{mg} / \mathrm{L})$.

The potential generation of more toxic organic compounds than the parent pollutant via the electro-Fenton process represents one of the main drawbacks associated with the use of this technology. Thus, adequate parameters such as the average oxidation state (AOS) and carbon oxidation state (COS) are often selected to analyse the proportion of biodegradable organic compounds present into the aqueous solution. These parameters are derived based upon TOC and COD evolution and described by Equations (25) and (26) [24,25]:

$$
\begin{aligned}
& \mathrm{AOS}=4 \times(\mathrm{TOC}-\mathrm{COD}) / \mathrm{TOC} \\
& \mathrm{COS}=4 \times\left(\mathrm{TOC}_{0}-\mathrm{COD}\right) / \mathrm{TOC}_{0}
\end{aligned}
$$


where $\mathrm{TOC}_{0}$ is the initial concentration of total organic carbon (mmol C/L), TOC the total organic carbon at time $\mathrm{t}(\mathrm{mmol} \mathrm{C} / \mathrm{L})$ and COD the chemical oxygen demand $\left(\mathrm{mmol} \mathrm{O}_{2} / \mathrm{L}\right)$ at time t. COS represents the carbon oxidation efficiency considering the carbon removed from the solution as gaseous $\mathrm{CO}_{2}$. Regarding $\mathrm{AOS}$, the maximum value +4 corresponds to the highest oxidised state of carbon, $\mathrm{CO}_{2}$, with the minimum value -4 corresponding to the most reduced state of carbon, $\mathrm{CH}_{4}$.

\section{Heterogeneous Catalysts}

Apart from the experimental variables mentioned above which affect the efficiency of heterogeneous electro-Fenton process, mass transfer limitations are considered an important drawback of these catalytic systems [26]. The catalytic reaction takes place after the diffusion step towards the catalyst particles (external/film diffusion) and through the pore within the particle (internal diffusion). As a consequence, the search for a novel heterogeneous catalyst able to reduce the mass transfer limitations represents a challenging milestone on the research community.

Many publications have demonstrated the potential of natural iron minerals including hematite, goethite and magnetite, to catalyse $\mathrm{H}_{2} \mathrm{O}_{2}$ decomposition to hydroxyl radicals (Figure 2A) [26,27]. Recently, Barhoumi et al. [27] assessed the viability of pyrite as a heterogeneous iron source for antibiotic degradation. At optimum conditions, around $96 \%$ mineralisation was achieved after $8 \mathrm{~h}$ treatment, suggesting pyrite as an adequate solid catalyst for the electro-Fenton process. The efficiency of the pyrite-based electroFenton process was associated with the self-regulator of iron dosage and $\mathrm{pH}$ in the system according to the Equations (27)-(29):

$$
\begin{gathered}
2 \mathrm{FeS}_{2}+7 \mathrm{O}_{2}+2 \mathrm{H}_{2} \mathrm{O} \rightarrow 2 \mathrm{Fe}^{2+}+4 \mathrm{SO}_{4}{ }^{2-}+4 \mathrm{H}^{+} \\
2 \mathrm{FeS}_{2}+14 \mathrm{H}_{2} \mathrm{O}_{2} \rightarrow 2 \mathrm{Fe}^{3+}+14 \mathrm{H}_{2} \mathrm{O}+4 \mathrm{SO}_{4}{ }^{2-}+2 \mathrm{H}^{+} \\
\mathrm{FeS}_{2}+14 \mathrm{Fe}^{3+}+8 \mathrm{H}_{2} \mathrm{O} \rightarrow 15 \mathrm{Fe}^{2+}+2 \mathrm{SO}_{4}{ }^{2-}+16 \mathrm{H}^{+}
\end{gathered}
$$

Additionally, the use of chalcopyrite has been evaluated by Droguett et al. (2020) for cephalexin degradation; this mineral possesses the same catalytic behaviour as pyrite, again acting as a self-regulator in the bulk solution (Equation (30)):

$$
\mathrm{CuFeS}_{2}+16 \mathrm{Fe}^{3+}+8 \mathrm{H}_{2} \mathrm{O} \rightarrow \mathrm{Cu}^{2+}+17 \mathrm{Fe}^{2+}+2 \mathrm{SO}_{4}^{2-}+16 \mathrm{H}^{+}
$$

Natural iron-based composites have been investigated for heterogeneous electroFenton process targeting removal of pharmaceuticals [28]. Iron nanoparticles have high reactivity in water, leading to high surface energy, oxidation and passivation processes. To overcome these drawbacks, transition metals, such as copper, have been incorporated with iron nanoparticles, resulting in the development of bimetallic nanoparticle composites. The synergetic effect of the physicochemical properties of each metal enhances both the degradation activity and stability, providing efficient electron transfer. Campos et al. [29] evaluated the removal of nafcillin from aqueous solution using iron and copper monometallic and bimetallic nanoparticles as electro-Fenton catalysts. They used bimetallic nanoparticles as the catalyst to overcome the limitations associated with the use of ferromagnetic materials. XRD and SEM characterisation confirmed the presence of metallic $\mathrm{Fe}, \mathrm{Cu}$ and $\mathrm{FeOOH}$ in addition to a range of morphologies attributed to formation of metal oxides. In line with the theory, the use of bimetallic nanoparticles catalysed the total removal of the antibiotic with lower treatment time than either monometallic nanoparticle. However, during catalyst reuse trials, the pollutant removal percentage decreased by up to $77 \%$ following three consecutive cycles due to the formation of oxides $\left(\mathrm{FeO}, \mathrm{Fe}_{2} \mathrm{O}_{3}\right.$ and $\left.\mathrm{CuFe} \mathrm{O}_{4}\right)$ on the nanoparticle surface. Similar results were obtained by Ghasemi et al. [15], who synthesised nano-layered double hydroxide (NLDH) compounds containing copper and iron, who studied catalytic activity toward gentamicin degradation. Their hydrotalcite structure promoted high surface area and ion-exchange, exhibiting negligible metal leaching and almost full antibiotic degradation under optimal conditions. 


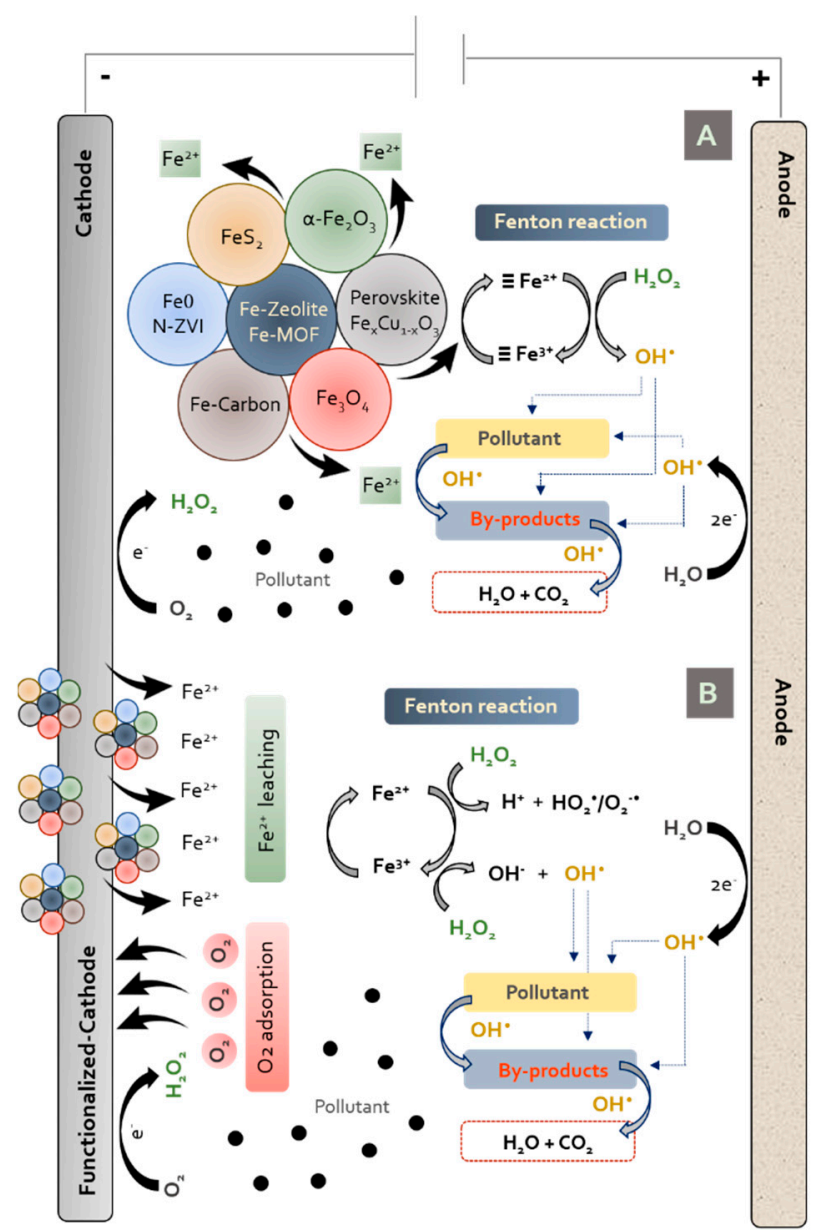

Figure 2. Mechanism of the catalytic activation on the heterogenous electro-Fenton process under acidic conditions: iron solid catalyst (A), iron-functionalised cathodic material (B).

Although the classical-Fenton reaction is based on $\mathrm{Fe}^{2+} / \mathrm{H}_{2} \mathrm{O}_{2}$, other transition metals such as copper, chromium, cobalt and manganese may promote $\mathrm{H}_{2} \mathrm{O}_{2}$ decomposition into ${ }^{\circ} \mathrm{OH}$ by 'Fenton-like' pathways. Copper, as described above, possesses similar redox behaviour to iron operating, under a similar broad $\mathrm{pH}$ range to the iron system. Given the importance of the role of the structure, several perovskites containing copper structures have been investigated. $\mathrm{LaCu}_{1-\mathrm{x}} \mathrm{M}_{\mathrm{x}} \mathrm{O}_{3}$ (where $\mathrm{M}=\mathrm{Mn}$, Ti; $0 \leq \mathrm{x} \leq 0.8$ ) was prepared and tested by Carrasco-Diaz et al. using paracetamol as the chemical probe under mild conditions and circumneutral $\mathrm{pH}$ [30]. Manganese and titanium were selected as the $\mathrm{B}$ position metals owing to their good activity in Fenton-like reactions. Based on their results, copper exhibited higher redox activity, whereas titanium and manganese were not responsible for the enhancement of antibiotic degradation. Negligible metal leaching and high metal stability within the network structure confirm this material as a promising alternative catalyst.

Novel composites containing iron species have been synthesised [31]. $\mathrm{Fe}_{2} \mathrm{O}_{3}$-modified kaolin was proposed by Özcan et al. [31] as a promising alternative for enoxacin degradation from aqueous environments. The use of clays such as kaolin and perlite has been widely applied primarily as catalyst supports due to their low cost, high adsorption ability and eco-friendly structure [32]. Carbonaceous materials have also been recently used as immobilisation substrates to enhance catalytic activity, stability and reusability. The incorporation of core-shell structured catalysts, with a transition metal nanoparticle core and a porous carbon shell, allows for enhanced catalytic properties whilst minimising catalyst agglomeration. $\mathrm{Fe} / \mathrm{Fe}_{3} \mathrm{C} @ \mathrm{PC}$ core-shell structured materials were synthesised by Du et al. [33] and tested for the degradation of sulfamethazine solutions. The aid with 
sustainability and catalyst reuse, this catalyst can be magnetically captured and further recovered via a thermal treatment in a $\mathrm{H}_{2}$ atmosphere. As was expected, $\mathrm{Fe} / \mathrm{Fe}_{3} \mathrm{C} @ \mathrm{PC}$ exhibited enhanced performance compared to the pristine iron oxides, given the synergetic effect between $\mathrm{Fe} / \mathrm{Fe}_{3} \mathrm{C}$ and $\mathrm{PC}$, again demonstrating the potential in nano-engineering to improve electro-Fenton catalyst form and function.

Graphene and its derivatives have also been considered suitable supporting materials for catalyst immobilisation due to their high thermal and electrical conductivity, strong mechanical and chemical stability, extremely high specific area and relatively simple synthesis methods from graphite (by chemical oxidation-exfoliation-reduction procedures and mechanical means). The oxygenated functional groups located on the edges (carbonyl and carboxyl) and basal plane (epoxides and hydroxyl) act as a nucleation site for metal ions to produce graphene-based nanocomposites [34].

\section{Heterogeneous Electro-Fenton Process with Iron Functionalised-Cathode}

Further work in the discipline of nano-engineering includes the use of three- dimensional electrodes in order to enhance the mass transfer and conductivity into the electro-Fenton system [35]. This innovative electrochemical system provided an enhanced effective contact area and numerous micro-electrolysis cells; therefore, the electrochemical reactions take places on the main electrode surface and the particle electrode surface. The cathodic-modification via the addition of iron and/or transition metal oxides, incorporates dual functionality, as both a counter electrode and an iron source, and may be carried out by the immobilisation of an iron source and/or through the chemical modification of the carbonaceous material.

Although these systems show high pollutant removal effectiveness, some operational limitations may hinder their widespread use in water purification, such as low current efficiency and narrow operating $\mathrm{pH}$ range. Mohammadi et al. [35] studied Fe-Ni foam particles on three-dimensional electrodes for NSAIDs removal using $\mathrm{Ti}-\mathrm{PbO}_{2}$ and graphite felt as the anode and cathode, respectively. This system achieved nearly a two-fold increase in the removal percentage when compared to a corresponding 2D electro-Fenton system. The authors attributed the increased rate to a higher concentration of radical species generation because the Ni-foam electrode may activate molecular oxygen to produce single oxygen. Recently, Luo et al. [20] proposed a Cu-doped $\mathrm{Fe}_{\mathrm{F}} \mathrm{Fe}_{2} \mathrm{O}_{3}$ core-shell nanoparticle (CFF) system loaded on a nickel-based foam as the cathode and examined efficiency for tetracycline degradation. XRD and XPS experiments allowed the determination of the catalyst composition showing an $\mathrm{Fe} / \mathrm{Cu}$ nanoparticle core and an external layer-shell of metal oxides $\left(\mathrm{Fe}_{2} \mathrm{O}_{3}, \mathrm{Cu}_{2} \mathrm{O}\right.$ and $\left.\mathrm{CuO}\right)$. Catalytic performance was reported to decline with increasing $\mathrm{Cu}$ content due to a reduction in active $\mathrm{Fe}^{0}$ sites. For optimal $\mathrm{Fe} / \mathrm{Cu}$ loadings, catalyst reusability was demonstrated over six successive runs with negligible iron leaching was observed.

The development of iron-functionalised cathodic materials (Figure 2B), such as active carbon/fibre, carbon felt, graphite felt and carbon aerogels, has recently received significant attention. In particular, Mi et al. [36] investigated the electrocatalytic performance of mesoporous $\mathrm{Mn}_{\mathrm{X}} \mathrm{Co}_{3-\mathrm{X}} \mathrm{O}_{4}$ nanoparticle modified carbon felt as an electro-Fenton cathode. Higher ciprofloxacin degradation rates were achieved as a result of increasing electron transfer and the redox reactivity. This was associated with the synergetic effect of embedded cobalt and manganese within the mesoporous matrix and promotion of more accessible active sites. The reusability of the modified cathode was evaluated via five successive cycles with minimal ion leaching measured (below 3.5 ppm). Similarly, Yang et al. [13] prepared heterogeneous $\mathrm{Fe}^{\mathrm{II}} \mathrm{Fe}^{\mathrm{III}}$-layered double hydroxide $\left(\mathrm{Fe}^{\mathrm{II}} \mathrm{Fe}^{\mathrm{III}} \mathrm{LDH}\right.$ ) modified carbon felt by an in situ solvothermal method for ofloxacin removal. Hydroxyl radical mediated mineralisation of ofloxacin was attributed to the formation of $\mathrm{BDD}\left({ }^{\bullet} \mathrm{OH}\right)$ via the electrochemical process and surface iron oxide catalysis through the $\mathrm{Fe}^{\mathrm{II}} \mathrm{Fe}{ }^{\mathrm{III}}$ cycle. These results support the work of Ganiyu et al. [37], who evaluated $\mathrm{Fe}^{\mathrm{II}} \mathrm{Fe}^{\mathrm{III}} \mathrm{LDH}$ modified carbon felt as cathode for sulfamethoxazole degradation. Nsubuga et al. [38] synthesised a $\mathrm{Cu}-\mathrm{B}-\mathrm{Fe}$ 
modified-graphite electrode and trailed the approach for the degradation of two $\beta$-blockers (atenolol and propranolol). As was previously observed, they also concluded that the bimetallic catalysts possess higher stability than monometallic electrode materials and additionally benefited from good thermal and recycling stability and conductivity. The use of magnetic single walled carbon nanotubes (MWCNTs) as a carrier for the electrocatalyst was reported by Pourzamani et al. [39]. These materials possess a high specific surface area, notable chemical and mechanical stability and high electrical conductivity. Comparative analysis between several electrocatalytic degradation technologies demonstrated MWCNTs to have a high efficiency and enhanced energy-saving than three-dimensional electrode systems, likely due to the significantly greater surface area of the MWCNTs and the strong interaction between $\mathrm{Fe}_{2} \mathrm{O}_{3}$ and MWCNTs.

\section{Application of Electro-Fenton Process for the Removal of Pharmaceutical Compounds}

Given the interest in new electro-Fenton processes for the remediation of low level, persistent, recalcitrant emerging water pollutants, and in particular pharmaceutical compounds, antibiotics, $\beta$-blockers and nonsteroidal anti-inflammatory drugs (NSAIDs) have been prominently featured in published research over last five years, as shown in the comprehensive summary (Tables 2 and 3). In this section, several investigations have been discussed based on the type of pharmaceutical compounds. Although the mineralisation pathways of these compounds depend on the molecular structure of the target pollutant and operational conditions, common oxidation steps take place on the degradation/mineralisation process by electro-Fenton-based processes. Succinctly, hydroxylation reactions on the side chain occur by the attack of hydroxyl radicals and hydroxylated cyclic hydrocarbons were obtained by the cleavage of $\mathrm{C}-\mathrm{S}, \mathrm{N}=\mathrm{N}, \mathrm{N}-\mathrm{N}, \mathrm{S}-\mathrm{N}, \mathrm{C}-\mathrm{N}, \mathrm{C}-\mathrm{C}$ and $\mathrm{C}=\mathrm{C}$ bonds. For instance, the $\mathrm{C}=\mathrm{C}$ bond on the tetracycline molecule has been reported as the most reactive position for the hydroxyl radical attack leading to the production of the major intermediate [13]. Further hydroxylation, decarboxylation, demethylation, deamination, desulfonation and dichlorination reactions, as well as ring opening steps lead to the formation of short-chain carboxylic acids reported as end-products prior to the total mineralisation up to carbon dioxide, water and inorganic ions. 
Table 2. Summary of some relevant studies on heterogeneous electro-Fenton systems.

\begin{tabular}{|c|c|c|c|c|c|}
\hline $\begin{array}{l}\text { Pharmaceutical } \\
\text { (Concentration) }\end{array}$ & $\begin{array}{c}\text { Catalyst } \\
\text { (Concentration) }\end{array}$ & Anode/Cathode & Operational Conditions & Removal and TOC Decay & References \\
\hline $\begin{array}{l}\text { Sulfamethazine } \\
(0.2 \mathrm{mM})\end{array}$ & $\begin{array}{l}\text { Pyrite } \\
(2 \mathrm{~g} / \mathrm{L})\end{array}$ & $\mathrm{BDD} / \mathrm{CF}$ & $\begin{array}{c}0.05 \mathrm{M} \mathrm{Na}_{2} \mathrm{SO}_{4}, \mathrm{pH}: 3 \\
\text { AFR: } 1 \mathrm{~L} / \mathrm{min}, \mathrm{I}=300 \mathrm{~mA}\end{array}$ & $100 \%$ removal (40 min) & {$[40]$} \\
\hline $\begin{array}{l}\text { Tetracycline } \\
(0.2 \mathrm{mM})\end{array}$ & $\begin{array}{l}\text { Pyrite } \\
(2 \mathrm{~g} / \mathrm{L})\end{array}$ & $\mathrm{BDD} / \mathrm{CF}$ & $\begin{array}{c}0.05 \mathrm{M} \mathrm{Na}_{2} \mathrm{SO}_{4}, \mathrm{pH}: 3 \\
\text { AFR: } 1 \mathrm{~L} / \mathrm{min}, \mathrm{I}=300 \mathrm{~mA}\end{array}$ & $\begin{array}{c}100 \% \text { removal }(20 \mathrm{~min}) \\
96 \% \text { TOC decay }(480 \mathrm{~min})\end{array}$ & {$[27]$} \\
\hline $\begin{array}{l}\text { Tetracycline } \\
(0.2 \mathrm{mM})\end{array}$ & $\begin{array}{l}\text { Chalcopyrite } \\
(1 \mathrm{~g} / \mathrm{L})\end{array}$ & $\mathrm{BDD} / \mathrm{CF}$ & $\begin{array}{c}0.05 \mathrm{M} \mathrm{Na}_{2} \mathrm{SO}_{4}, \mathrm{pH}: 5.94 \\
\text { AFR: } 0.6 \mathrm{~L} / \mathrm{min}, \mathrm{I}=300 \mathrm{~mA}\end{array}$ & $\begin{array}{c}100 \% \text { removal }(7 \mathrm{~min}) \\
85 \% \text { TOC decay }(120 \mathrm{~min})\end{array}$ & [17] \\
\hline $\begin{array}{l}\text { Cephalexin } \\
(50 \mathrm{mg} / \mathrm{L})\end{array}$ & $\begin{array}{l}\text { Chalcopyrite } \\
(1 \mathrm{~g} / \mathrm{L})\end{array}$ & $\mathrm{IrO}_{2} /$ air diffusion cathode & $\begin{array}{c}0.05 \mathrm{M} \mathrm{Na}_{2} \mathrm{SO}_{4}, \mathrm{pH}: 3 \\
\text { AFR: } 0.6 \mathrm{~L} / \mathrm{min}, \mathrm{I}=125 \mathrm{~mA}\end{array}$ & $\begin{array}{c}94 \% \text { removal (15 min) } \\
44 \% \text { TOC decay (300 min) }\end{array}$ & [16] \\
\hline $\begin{array}{l}\text { Metronidazole } \\
\quad(70 \mathrm{mg} / \mathrm{L})\end{array}$ & $\begin{array}{l}\mathrm{Nano}-\mathrm{Fe}_{2} \mathrm{O}_{3} \\
\quad(1 \mathrm{~g} / \mathrm{L})\end{array}$ & Pt sheet/GF & $\begin{array}{c}0.05 \mathrm{M} \mathrm{Na}_{2} \mathrm{SO}_{4}, \mathrm{pH}: 3 \\
\mathrm{I}=200 \mathrm{~mA}\end{array}$ & $92.3 \%$ removal (30 min) & {$[41]$} \\
\hline $\begin{array}{l}\text { Amoxicillin } \\
(20 \mathrm{mg} / \mathrm{L})\end{array}$ & $\begin{array}{c}\mathrm{Nano}-\mathrm{Fe}_{2} \mathrm{O}_{3} \\
(1 \mathrm{~g} / \mathrm{L})\end{array}$ & Pt sheet/GF & $\begin{array}{c}0.01 \mathrm{M} \mathrm{Na}_{2} \mathrm{SO}_{4}, \mathrm{pH}: 3 \\
\text { AFR: } 1 \mathrm{~L} / \mathrm{min}, \mathrm{I}=300 \mathrm{~mA}\end{array}$ & $98.2 \%$ removal (60 min) & {$[42]$} \\
\hline $\begin{array}{l}\text { Diclofenac } \\
(140 \mathrm{mg} / \mathrm{L})\end{array}$ & $\begin{array}{c}\mathrm{Fe}_{2} \mathrm{O}_{3}-\text { modified chitosan } \\
(20 \mathrm{~g} / \mathrm{L})\end{array}$ & $\mathrm{BDD} / \mathrm{CF}$ & $\begin{array}{c}0.01 \mathrm{M} \mathrm{Na}_{2} \mathrm{SO}_{4}, \mathrm{pH}: 6 \\
\text { AFR: } 1 \mathrm{~L} / \mathrm{min}, \mathrm{I}=300 \mathrm{~mA}\end{array}$ & $\begin{array}{l}95 \% \text { removal }(120 \mathrm{~min}) \\
74.4 \% \text { TOC decay }(8 \mathrm{~h})\end{array}$ & [43] \\
\hline $\begin{array}{l}\text { Enoxacin } \\
(0.25 \mathrm{mM})\end{array}$ & $\begin{array}{c}\mathrm{Fe}_{2} \mathrm{O}_{3}-\text { modified kaolin } \\
(1.7 \mathrm{~g} / \mathrm{L})\end{array}$ & $\mathrm{BDD} / \mathrm{CF}$ & $\begin{array}{c}0.05 \mathrm{M} \mathrm{Na}_{2} \mathrm{SO}_{4}, \mathrm{pH}: 3 \\
\text { AFR: } 1 \mathrm{~L} / \mathrm{min}, \mathrm{I}=300 \mathrm{~mA}\end{array}$ & $\begin{array}{c}100 \% \text { removal }(15 \mathrm{~min}) \\
98 \% \text { TOC decay }(420 \mathrm{~min})\end{array}$ & [31] \\
\hline $\begin{array}{l}\text { Diclofenac } \\
(10 \mathrm{mg} / \mathrm{L})\end{array}$ & $\begin{array}{l}\text { MSWCNTs-FeCl } \\
\quad(80 \mathrm{mg} / \mathrm{L})\end{array}$ & $\mathrm{Ti}-\mathrm{RuO}_{2} / \mathrm{GF}$ & $\begin{array}{c}0.05 \mathrm{M} \mathrm{Na}_{2} \mathrm{SO}_{4}, \mathrm{pH}: 5 \\
\text { AFR: } 1 \mathrm{~mL} / \mathrm{min}, \mathrm{d}=20 \mathrm{~mA} / \mathrm{cm}^{2}\end{array}$ & $\begin{array}{c}97.8 \% \text { removal }(120 \mathrm{~min}) \\
71 \% \text { TOC decay }(120 \mathrm{~min})\end{array}$ & {$[44]$} \\
\hline $\begin{array}{l}\text { Gentamicin } \\
(20 \mathrm{mg} / \mathrm{L})\end{array}$ & $\begin{array}{l}\mathrm{Cu}-\mathrm{Fe}-\mathrm{NLDH} \\
(1.25 \mathrm{~g} / \mathrm{L})\end{array}$ & Pt sheet/graphite plate & $\begin{array}{c}0.05 \mathrm{M} \mathrm{Na}_{2} \mathrm{SO}_{4}, \mathrm{pH}: 6, \\
\text { AFR: } 10 \mathrm{~L} / \mathrm{h}, \mathrm{I}=400 \mathrm{~mA}\end{array}$ & 91.3\% removal (100 min) & [15] \\
\hline $\begin{array}{l}\text { Nafcillin } \\
(36 \mathrm{mg} / \mathrm{L})\end{array}$ & $\begin{array}{l}\mathrm{Fe} / \mathrm{Cu} \text { bimetallic nanoparticles } \\
\qquad(1 \mathrm{~g} / \mathrm{L})\end{array}$ & $\begin{array}{l}\text { BDD/carbon-PTFE air } \\
\text { diffusion }\end{array}$ & $\begin{array}{c}0.05 \mathrm{M} \mathrm{Na}_{2} \mathrm{SO}_{4}, \mathrm{pH}: 7 \\
\mathrm{~d}=5 \mathrm{~mA} / \mathrm{cm}^{2}\end{array}$ & $100 \%$ removal $(7 \mathrm{~min})$ & [29] \\
\hline $\begin{array}{l}\text { Chloramphenicol } \\
\quad(80 \mathrm{mg} / \mathrm{L})\end{array}$ & $\begin{array}{l}\mathrm{Fe}_{3} \mathrm{O}_{4}-\mathrm{GO} \\
(0.5 \mathrm{~g} / \mathrm{L})\end{array}$ & Pt gauze/CF & $\begin{array}{c}0.05 \mathrm{M} \mathrm{Na}_{2} \mathrm{SO}_{4}, \mathrm{pH}: 3, \\
\text { AFR: } 10 \mathrm{~L} / \mathrm{h}, \mathrm{I}=300 \mathrm{~mA}\end{array}$ & $\begin{array}{c}100 \% \text { removal }(45 \mathrm{~min}) \\
86 \% \text { TOC decay }(300 \mathrm{~min})\end{array}$ & {$[45]$} \\
\hline $\begin{array}{l}\text { Metronidazole } \\
\quad(80 \mathrm{mg} / \mathrm{L})\end{array}$ & $\begin{array}{l}\mathrm{Fe}_{3} \mathrm{O}_{4}-\mathrm{GO} \\
(0.5 \mathrm{~g} / \mathrm{L})\end{array}$ & Pt gauze/CF & $\begin{array}{c}0.05 \mathrm{M} \mathrm{Na}_{2} \mathrm{SO}_{4}, \mathrm{pH}: 3 \\
\text { AFR: } 10 \mathrm{~L} / \mathrm{h}, \mathrm{I}=300 \mathrm{~mA}\end{array}$ & $\begin{array}{c}100 \% \text { removal }(15 \mathrm{~min}) \\
73 \% \text { TOC decay }(300 \mathrm{~min})\end{array}$ & {$[45]$} \\
\hline
\end{tabular}


Table 2. Cont.

\begin{tabular}{|c|c|c|c|c|c|}
\hline $\begin{array}{l}\text { Pharmaceutical } \\
\text { (Concentration) }\end{array}$ & $\begin{array}{c}\text { Catalyst } \\
\text { (Concentration) }\end{array}$ & Anode/Cathode & Operational Conditions & Removal and TOC Decay & References \\
\hline $\begin{array}{l}\text { Propranolol/acebutolol } \\
\text { (200 ng/mL each) }\end{array}$ & $\begin{array}{c}\mathrm{Fe}-\mathrm{C} \\
(119 \mathrm{mg} / \mathrm{L})\end{array}$ & BDD/air diffusion cathode & $\begin{array}{c}0.05 \mathrm{M} \mathrm{Na}_{2} \mathrm{SO}_{4}, \mathrm{pH}: 7 \\
\mathrm{~d}=75 \mathrm{~mA} / \mathrm{cm}^{2}\end{array}$ & $100 \%$ removal (15 min) & {$[46]$} \\
\hline $\begin{array}{l}\text { Diclofenac } \\
(50 \mathrm{mg} / \mathrm{L})\end{array}$ & $\begin{array}{l}\text { Pyrite } \\
(8 \mathrm{~g} / \mathrm{L})\end{array}$ & $\begin{array}{l}\text { Pt mesh/air diffusion } \\
\text { cathode }\end{array}$ & $\begin{array}{c}0.05 \mathrm{M} \mathrm{Na}_{2} \mathrm{SO}_{4}, \mathrm{pH}: 7 \\
\text { AFR: } 0.4 \mathrm{~L} / \mathrm{min}, \mathrm{d}=31.84 \mathrm{~mA} / \mathrm{cm}^{2}\end{array}$ & $\begin{array}{c}97.8 \% \text { removal }(8 \mathrm{~min}) \\
85 \% \text { TOC decay }(180 \mathrm{~min})\end{array}$ & [47] \\
\hline $\begin{array}{l}\text { Gemfibrozil } \\
(10 \mathrm{mg} / \mathrm{L})\end{array}$ & $\begin{array}{c}\text { nano-ZVI@C-N } \\
(0.2 \mathrm{~g} / \mathrm{L})\end{array}$ & $\mathrm{Ti}-\mathrm{IrO}_{2} /$ air diffusion cathode & $\begin{array}{c}0.05 \mathrm{M} \mathrm{Na}_{2} \mathrm{SO}_{4}, \mathrm{pH}: 6 \\
\text { AFR: } 1 \mathrm{~L} / \mathrm{min}, \mathrm{I}=300 \mathrm{~mA}\end{array}$ & $95 \%$ removal $(60 \mathrm{~min})$ & [48] \\
\hline
\end{tabular}

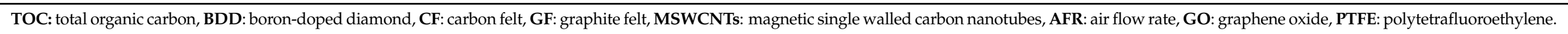

Table 3. Summary of some relevant studies on heterogeneous electro-Fenton systems using iron-functionalised cathode.

\begin{tabular}{|c|c|c|c|c|c|}
\hline $\begin{array}{l}\text { Pharmaceutical } \\
\text { (Concentration) }\end{array}$ & $\begin{array}{c}\text { Catalyst } \\
\text { (Concentration) }\end{array}$ & Anode/Cathode & Operational Conditions & Removal and TOC Decay & References \\
\hline $\begin{array}{l}\text { Ibuprofen } \\
(10 \mathrm{mg} / \mathrm{L})\end{array}$ & Ferric citrate & $\mathrm{Ti}-\mathrm{RuO}_{2} / \mathrm{Cit}-\mathrm{Fe}-\mathrm{ACFs}$ & $\begin{array}{c}0.05 \mathrm{M} \mathrm{Na}_{2} \mathrm{SO}_{4}, \mathrm{pH}: 6.8 \\
\text { AFR: } 0.1 \mathrm{~L} / \mathrm{min}, \mathrm{d}=5 \mathrm{~mA} / \mathrm{cm}^{2}\end{array}$ & $97 \%$ removal (120 $\mathrm{min})$ & [49] \\
\hline $\begin{array}{l}\text { Sulfamethazine } \\
(10 \mathrm{mg} / \mathrm{L})\end{array}$ & $\begin{array}{c}\mathrm{Fe} / \mathrm{Fe}_{3} \mathrm{C} @ \mathrm{CP} \\
(0.05 \mathrm{~g} / \mathrm{L})\end{array}$ & $\mathrm{Ti}-\mathrm{RuO}_{2} / \mathrm{CB}-\mathrm{CF}$ & $\begin{array}{c}0.05 \mathrm{M} \mathrm{Na}_{2} \mathrm{SO}_{4}, \mathrm{pH}: 3 \\
\mathrm{I}=25 \mathrm{~mA}\end{array}$ & $99 \%$ removal (30 $\mathrm{min})$ & [33] \\
\hline $\begin{array}{l}\text { Levofloxacin } \\
(80 \mathrm{mg} / \mathrm{L})\end{array}$ & $\begin{array}{c}\mathrm{Fe} / \mathrm{Fe}_{3} \mathrm{C} @ \mathrm{CP} \\
(0.05 \mathrm{~g} / \mathrm{L})\end{array}$ & $\mathrm{Ti}-\mathrm{RuO}_{2} / \mathrm{CB}-\mathrm{CF}$ & $\begin{array}{c}0.05 \mathrm{M} \mathrm{Na}_{2} \mathrm{SO}_{4}, \mathrm{pH}: 3 \\
\mathrm{I}=25 \mathrm{~mA}\end{array}$ & $97 \%$ removal $(60 \mathrm{~min})$ & [33] \\
\hline $\begin{array}{l}\text { Ibuprofen } \\
(4 \mathrm{mg} / \mathrm{L})\end{array}$ & Fe-NFP & $\mathrm{Ti}-\mathrm{PbO}_{2} / \mathrm{GF}$ & $\mathrm{pH}: 6.3, \mathrm{~d}=15.77 \mathrm{~mA} / \mathrm{cm}^{2}$ & $98 \%$ removal (38 min) & {$[35]$} \\
\hline $\begin{array}{l}\text { Naproxen } \\
(4 \mathrm{mg} / \mathrm{L})\end{array}$ & Fe-NFP & $\mathrm{Ti}-\mathrm{PbO}_{2} / \mathrm{GF}$ & $\mathrm{pH}: 6.24, \mathrm{~d}=18.91 \mathrm{~mA} / \mathrm{cm}^{2}$ & $93 \%$ removal (38 $\mathrm{min})$ & [35] \\
\hline $\begin{array}{l}\text { Diclofenac } \\
(6.71 \mathrm{mg} / \mathrm{L})\end{array}$ & $\begin{array}{l}\text { MSWCNTs-Fe }{ }_{3} \mathrm{O}_{4} \\
\quad(58.33 \mathrm{mg} / \mathrm{L})\end{array}$ & $\mathrm{Ti}-\mathrm{RuO}_{2} / \mathrm{MSWCNTs}-\mathrm{Fe}_{3} \mathrm{O}_{4}-\mathrm{GF}$ & $\begin{array}{c}0.05 \mathrm{M} \mathrm{Na}_{2} \mathrm{SO}_{4}, \mathrm{pH}: 5.56 \\
\text { AFR: } 1 \mathrm{~mL} / \mathrm{min} \\
\mathrm{d}=19.74 \mathrm{~mA} / \mathrm{cm}^{2}\end{array}$ & $98 \%$ removal $(83 \mathrm{~min})$ & [39] \\
\hline $\begin{array}{l}\text { Ciprofloxacin } \\
(0.1 \mathrm{mM})\end{array}$ & $\mathrm{Fe}^{2+}(0.1 \mathrm{mM}) / \mathrm{MnCo}_{2} \mathrm{O}_{4}$ & Pt plate $/ \mathrm{MnCo}_{2} \mathrm{O}_{4}-\mathrm{CF}$ & $\begin{array}{c}0.05 \mathrm{M} \mathrm{Na}_{2} \mathrm{SO}_{4}, \mathrm{pH}: 3 \\
\text { AFR: } 10 \mathrm{~L} / \mathrm{h}, \mathrm{I}=300 \mathrm{~mA}\end{array}$ & $\begin{array}{c}100 \% \text { removal }(300 \mathrm{~min}) \\
75 \% \text { TOC decay }(300 \mathrm{~min})\end{array}$ & {$[36]$} \\
\hline
\end{tabular}


Table 3. Cont.

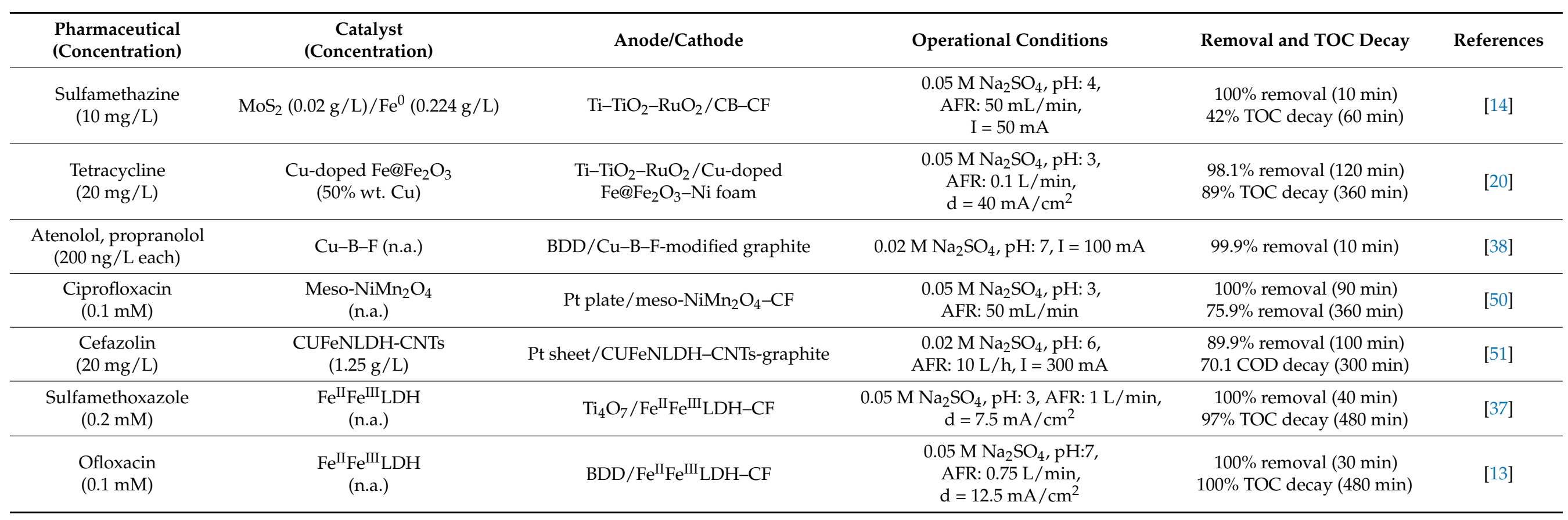

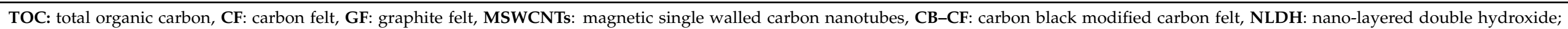
AFR: air flow rate, CNTs: carbon nanotubes, NFP: nickel foam particles. 


\subsection{Antibiotics}

The widespread overuse of antibiotics, mainly in primary care, and poor removal efficiency in WWTP results in trace level antibiotics being considered a significant hazard to both environment and human health. Tetracycline, used to control the urinary tract, respiratory tract and the intestinal infections has been detected in natural water at concentrations up to $1.4 \mu \mathrm{g} / \mathrm{L}$ [27]; likewise, ciprofloxacin, widely used against a range of bacterial infections has been detected at concentrations ranging from $0.407 \mathrm{nmol} / \mathrm{L}$ in Europe to 20,000 nmol/L in Asia [52].

Fluoroquinones including ciprofloxacin, levofloxacin or ofloxacin have been detected in aquatic ecosystems and drinking water at concentrations around ng/L [36]. Mi et al. [36] examined the effectiveness of carbon felt modified with $\mathrm{Mn}_{\mathrm{X}} \mathrm{Co}_{3-\mathrm{X}} \mathrm{O}_{4}$ mesoporous nanoparticles for ciprofloxacin removal. SEM images showed the successful deposition of $\mathrm{MnCo}_{2} \mathrm{O}_{4}$ nanoparticles on the carbon felt surface and uniform distribution of the elements within the nanoparticles. Based on cyclic voltammetry analysis, the authors concluded that higher intrinsic electron transfer promoted increased redox reaction capacity due to the synergetic effect between the transition metals in the mesoporous structure. Electron-density distribution analysis showed Co to be present as an electron-rich species (e.g., cobalt oxides) with the uniform nature of the total electron density map suggesting an electron transfer from $\mathrm{Co}$ to $\mathrm{Mn}$. Furthermore, the large specific surface area, notable $\mathrm{H}_{2} \mathrm{O}_{2}$ yield and excellent hydroxyl radical production rate promoted high levels of ciprofloxacin removal. Similar results were obtained by Du et al. [33], who degraded levofloxacin using $\mathrm{Fe} / \mathrm{Fe}_{3} \mathrm{C}$ and graphitised porous carbon shell systems. A particular benefit of this system is the inherent magnetic property which permits the post-treatment separation of the particles, recycling and reuse. From their results, the saturation magnetisation decreased from 70.1 up to $49.5 \mathrm{emu} / \mathrm{g}$ after use due to leaching of iron and the deposition of iron oxides on the particles during pollutant degradation experiments.

Yang et al. [13] also analysed supported catalysis, investigating the performance of $\mathrm{Fe}^{\mathrm{II}} \mathrm{Fe}^{\mathrm{III}}$-LHD modified carbon felt cathodes for ofloxacin removal at near neutral $\mathrm{pH}$. Complete TOC abatement was attained after a $480 \mathrm{~min}$ treatment in a system applying a current density of $9.37 \mathrm{~mA} / \mathrm{cm}^{2}$. Notable removal efficiency was observed at $\mathrm{pH} 7$ as a result of the surface catalysed process at the solid-liquid interface, preventing the precipitation of iron hydroxide. The authors calculated the electroactive surface of the modified cathode and unmodified materials to determine the rate of the electrochemical reactions on the cathode, using cyclic voltammetry runs in a $10 \mathrm{mM}\left[\mathrm{Fe}(\mathrm{CN})_{6}\right]^{3-} /\left[\mathrm{Fe}(\mathrm{CN})_{6}\right]^{4-}$ solution with the electroactive surface estimated by Randles-Sevcik equation (Equation (31)):

$$
\mathrm{I}_{\mathrm{P}}=2.69 \times 10^{5} \times \mathrm{A} \times \mathrm{D}^{1 / 2} \times \mathrm{n}^{1 / 2} \times v^{1 / 2} \times \mathrm{C}
$$

where $I_{P}$ is the maximum peak current $(A), n$ is the number of electrons involved in the redox reaction $(\mathrm{n}=1), \mathrm{A}$ is the area of the electrode $\left(\mathrm{cm}^{2}\right), \mathrm{D}$ is the diffusion coefficient of the molecule in the solution $\left(7.6 \times 10^{-6} \mathrm{~cm}^{2} / \mathrm{s}\right), \mathrm{C}$ is the concentration of the standard molecule in the bulk solution $\left(10^{-5} \mathrm{~mol} / \mathrm{mL}\right)$ and $v$ is the scan rate $(0.01 \mathrm{~V} / \mathrm{s})$.

Accordingly, the electroactive surface area was calculated to be $42 \mathrm{~cm}^{2}$ for the raw carbon felt and $127 \mathrm{~cm}^{2}$ with the $\mathrm{Fe}^{\mathrm{II}} \mathrm{Fe}^{\mathrm{III}} \mathrm{LDH}$-modified $\mathrm{CF}$, thus, a three-fold improvement in surface area resulted in the increased performance of the electrocatalytic reactions on the cathode. Consequently, the increasing current density impacted on the economic parameters (MCE and EC) and parallel reactions were observed, such as $\mathrm{H}_{2}$ evolution on the cathode and $\mathrm{O}_{2}$ formation on the anode. Positive outcomes included negligible iron leaching demonstrating catalyst stability at circumneutral $\mathrm{pH}$.

Tetracyclines represent another common class of antibiotics, with many studies targeting their removal. The use of iron-based minerals such as pyrite and chalcopyrite was investigated by Oturan and Brillas groups $[17,27]$ achieving a $100 \%$ removal of tetracycline $\left(\mathrm{C}_{22} \mathrm{H}_{24} \mathrm{~N}_{2} \mathrm{O}_{8}\right)$ in less than 20 min. Under similar operational conditions, the use of chalcopyrite as a catalyst exhibited a higher degree of mineralisation due to the contribution of copper ions. Given the complexity of the tetracycline molecule, the formation of 
recalcitrant intermediate products results in significant impact on MCE depletion which is accompanied by an increase in energy consumption per TOC unit. Therefore, the authors suggested a sequential process based on the chalcopyrite/electro-Fenton process followed by conventional treatments for practical applications.

Droguett et al. [16] evaluated the potential use of chalcopyrite as a heterogeneous catalyst to degrade cephalexin achieving a 94\% removal of the parent compound within $30 \mathrm{~min}$ treatment, however, as can be seen in Table 2, only $44 \%$ mineralisation was reached after $300 \mathrm{~min}$ due to the emergence of recalcitrant intermediates, such as aromatic compounds and short-chain carboxylic acids, the latter leading to the formation of stable organo-iron complexes, which cannot be degraded by hydroxyl radicals. Ecotoxicological effects of these by-products of electro-Fenton treatment are often evaluated by classical toxicity studies including Vibrio fischeri (Microtox®test), Daphnia magna or Escherichia coli as model organisms used to assess the general toxicity of the effluent produced from treatment.

Sulphonamide antibiotics, such as sulfamethazine, possess antibacterial activity being widely used for human and veterinary clinical purposes $[53,54]$ and as a consequence has been detected in effluents from the sewage treatment plant and surface water at concentrations ranging from 20 to $1000 \mathrm{ng} / \mathrm{L}$ [55]. Many researchers have studied this group of antibiotics over the last five years using a heterogeneous electro-Fenton process (Table 2) $[14,33,40]$. Tian et al. [14] used commercial $\mathrm{MoS}_{2}$ as a co-catalyst to develop an efficient $\mathrm{MoS}_{2} / \mathrm{Fe}^{0}$ co-catalytic electro-Fenton process. Almost complete sulfamethazine degradation was achieved after $20 \mathrm{~min}$ by $\mathrm{Fe}^{0}$-electro-Fenton process whereas only $10 \mathrm{~min}$ were necessary to achieve the same removal percentage when $\mathrm{MoS}_{2}$ was introduced as a cocatalyst. These results concur with the data for homogeneous electro-Fenton process, with a higher sulfamethazine removal rate evident in the presence of the co-catalyst. The effect was attributed to the acceleration of the $\mathrm{Fe}^{3+} / \mathrm{Fe}^{2+}$ reactions (Equation (14)) with an associated increase in the generation of hydroxyl radicals (Equation (17)) experimentally demonstrated. Similar sulfamethazine degradation studies were also reported by Barhoumi et al. [40] and Du et al. [33].

The degradation of sulfamethizole was undertaken by Puga et al. [32], who used electro-Fenton process in ultrapure water and real treated wastewater spiked with the pollutant (final concentration around $25 \mathrm{mg} / \mathrm{L}$ ) under a continuous flow-system. The authors assumed a first-order kinetic model for mineralisation data reporting kinetic rate constants around 0.27 and $0.151 / \mathrm{h}$ for ultrapure and real water, respectively, demonstrating the challenge of working with real effluent. Campos et al. [29] also observed this effect, reporting the influence of feed water composition on radical scavenging reactions coupled with mass transfer limitations due to the presence of organic matter. Under optimal conditions, nafcillin was completely removed from the slaughterhouse effluent after $15 \mathrm{~min}$ treatment, demonstrating efficacy in a very challenging wastewater matrix. A range of other works report similar behaviour $[49,56]$ within limited TOC reduction observed in effluent-based experiments.

$\beta$-lactam antibiotics, including penicillin, are a group of compounds commonly used to treat a wide range of bacterial infections. Amoxicillin, a well-known broad-spectrum $\beta$-lactam is non-biodegradable and detected in groundwater, surface waters, hospital effluents and industrial wastewater streams at concentrations ranging from sub-ng/L up to $87.5 \mathrm{~g} / \mathrm{L}$ [57]. Their toxic and recalcitrant character hinders removal by conventional biological treatments and thus, the use of AOPs including Fenton-based processes have been investigated for amoxicillin degradation [58-60]. Kalantary et al. [42] studied the performance of a heterogeneous electro-Fenton process using nano- $\mathrm{Fe}_{3} \mathrm{O}_{4}$ modified-carbon felt cathodes which increased the $\mathrm{H}_{2} \mathrm{O}_{2}$ yield 5.2-fold without aeration, demonstrating promise for the application of the electro-Fenton process at low oxygen levels. Optimisation of the process was carried out to ensure the minimum applied current and as such deliver an economic and energy favourable process, with the authors reporting a tenfold decrease in terms of energetic consumption (Equation (23)) within a minimal impact on process effectiveness ( $9 \%$ decrease from optimal efficiency). 
Chloramphenicol, a broad-spectrum antibiotic used in veterinary medicine, and although banned in the European Union and many other countries due to its harmful effects detected in humans, has been detected in food products arriving from Asia [61]. Several authors have reported the applicability of AOPs to degrade chloramphenicol by hydroxyl and sulphate radical-based mechanisms [62,63]. Görmez et al. [45] reported the potential of $\mathrm{GO}-\mathrm{Fe}_{3} \mathrm{O}_{4}$ as an electro-Fenton catalyst, noting around $80 \%$ mineralisation following 300 min treatment under optimal conditions with 16\% higher TOC removal when compared to the homogeneous electro-Fenton process. The authors suggested relatively higher activation energy was required for the initiation step of the degradation reaction due to the slow decay of the parent compound. Adsorption studies confirmed that the GO$\mathrm{Fe}_{2} \mathrm{O}_{3}$ catalyst contributed directly to the Fenton reaction rather than simply increasing pollutant adsorption.

Nitroimidazole antibiotics, including metronidazole, have been widely used to treat infections caused by anaerobic and protozoan bacteria and have been detected in hospital effluents at concentrations in the range of 1.8-9.4 $\mu \mathrm{g} / \mathrm{L}$ [64]. Their low biodegradability, high solubility in water and complex molecular structure hinder their removal by conventional systems [65]. Thus, Rahmatinia and Rahmatinia [41] studied metronidazole removal using nano- $\mathrm{Fe}_{3} \mathrm{O}_{4}$ as a heterogeneous catalyst reaching $92.2 \%$ removal under optimal conditions $(70 \mathrm{mg} / \mathrm{L}$ initial concentration, $\mathrm{pH} \mathrm{3,} 200 \mathrm{~mA}$ applied current intensity and $3.2 \mathrm{kWh} / \mathrm{m}^{3}$ ). Similar results have been reported by Görmez et al. [45] with data showing near total degradation after 15 min treatment.

\section{2. $\beta$-Blockers}

Beta adrenergic antagonists ( $\beta$-blockers) have been widely prescribed to treat cardiac arrhythmias, hypertension and angina, and are commonly detected illegally during antidoping controls $[66,67]$ with transport to the environment reported via effluents from pharmaceuticals plants, hospitals, retirement homes and private households [68].

$\beta$-blockers are considered a significant threat to the aquatic organisms due to their high persistence and bioaccumulation in water bodies [69,70]. Nsubuga et al. [46] developed a promising approach for the total elimination of parent propranolol and acebutolol, and their metabolites, using $\mathrm{Fe}-\mathrm{C}$ nanocomposites synthesised from rice husk. The use of a droplet flow-assisted heterogenous electro-Fenton reactor ensured synergetic mechanisms of degradation enhancement based on an increased surface area from the droplet chemistry and micro-electrolysis arising from the $\mathrm{Fe}-\mathrm{C}$ nanocomposite [46]. $\mathrm{pH}$ adjustment was not required given the nature of the biogenic iron composites which self-regulate acidity as observed in pyrite and chalcopyrite systems. The authors suggested an electrochemical degradation pathway based on the side chain cleavage to form an amino-diol and hydroxylation of the aromatic ring. Subsequently, Nsubuga et al. [38] analysed copper-boron-ferrite (Cu-B-Fe)-supported graphite electrodes using droplet flow-assisted heterogenous electroFenton process for atenolol and propranolol in hospital effluent. SEM images showed a high dispersion of the $\mathrm{Cu}, \mathrm{B}$ and $\mathrm{Fe}$ on the functionalised cathodic surface. Furthermore, near rectangular shaped cyclic voltammograms of these modified electrodes confirm their high potential to increase electron transfer on the electrode surfaces. Consequently, these electrodes demonstrated excellent activity for in situ $\mathrm{H}_{2} \mathrm{O}_{2}$ electrogeneration, hydroxyl radical production and catalyst regeneration.

\subsection{NSAIDs}

NSAIDs are frequently prescribed to treat pain and inflammation associated with arthritis, including acetaminophen (paracetamol), ibuprofen, naproxen and diclofenac; however, few publications have evaluated the production and fate of oxidation by-products and their ecotoxicological effects [71]. Given the routine detection in the aquatic environment [72], the EU Water Framework Directive lists ibuprofen within the first Watch List given regular detection in freshwater and wastewater treatment plant effluents at concentrations over $30 \mu \mathrm{g} / \mathrm{L}$ [73]. Liu et al. [49] reported the use of activated carbon fibre 
supported ferric citrate as a modified cathode, achieving $96 \%$ ibuprofen degradation at $5 \mathrm{~mA} / \mathrm{cm}^{2}$ current density after $120 \mathrm{~min}$ treatment. High MCE, around $46 \%$, was obtained in comparison with other heterogeneous electro-Fenton processes [31,40]. In addition, this modified cathode is also suitable for use at circumneutral $\mathrm{pH}$ similar to $\mathrm{Fe}_{2} \mathrm{O}_{3} /$ kaolin catalysts [31].

Diclofenac is a popular choice of model compound within the scientific community $[39,43,44]$ and has been detected in surface water and groundwater at concentration levels ranging from $0.8 \mathrm{ng} / \mathrm{L}$ to $4.4 \mu \mathrm{g} / \mathrm{L}$ [74-76]. Its high solubility at neutral-alkaline conditions and low solubility at $\mathrm{pH} \leq \mathrm{pKa}$ (around 4.91) considerably hinder its removal by conventional treatments $[77,78]$. Rosales et al. [43] have proposed an innovative approach at near neutral $\mathrm{pH}$ by using iron chitosan-epichlorohydrin spheres. Previously, Pourzamani et al. [39] reported good removal efficiency using 3D electro-Fenton process based upon multi-walled carbon nanotubes (MWCNTs)- $\mathrm{Fe}_{3} \mathrm{O}_{4}$ as the electrode. More than $70 \%$ degradation was achieved following $120 \mathrm{~min}$, a two-fold increase over heterogeneous electro-Fenton process without cathodic-modification demonstrating the effectiveness of the microelectrodes to increase both indirect and direct oxidation. In addition, less $\mathrm{H}_{2} \mathrm{O}_{2}$ accumulation was detected in the bulk solution as a result of rapid decomposition to hydroxyl radicals [79]. Similar enhancement was reported by Sadeghi et al. [44] using Fe-MWCNTs as the heterogeneous catalyst.

\section{Photoelectro-Fenton Process}

The effectiveness of the heterogenous electro-Fenton process may be enhanced through combination with other technologies. Hybrid processes integrated into systems, sequential alternative and successive treatments have been proposed with many examples reporting total pollutant removal from wastewater (summarised in Table 4). Photoelectro-Fenton (PEF) process represents an 'upgrade' to electro-Fenton via the simultaneous exposure of the solution to UV and/or visible radiation [80] (Figure 3).

Table 4. Summary of some relevant studies on heterogenous photoelectro-Fenton systems.

\begin{tabular}{|c|c|c|c|c|c|c|}
\hline $\begin{array}{l}\text { Pharmaceutical } \\
\text { (Concentration) }\end{array}$ & $\begin{array}{c}\text { Catalyst } \\
\text { (Concentration) }\end{array}$ & Anode/Cathode & $\begin{array}{l}\text { Operational } \\
\text { Conditions }\end{array}$ & Light Source & $\begin{array}{l}\text { Removal and } \\
\text { TOC Decay }\end{array}$ & References \\
\hline $\begin{array}{l}\text { Cephalexin } \\
(50 \mathrm{mg} / \mathrm{L})\end{array}$ & $\begin{array}{l}\text { Chalcopyrite } \\
\text { (1 g/L })\end{array}$ & $\begin{array}{l}\mathrm{IrO}_{2} / \text { air } \\
\text { diffusion } \\
\text { cathode }\end{array}$ & $\begin{array}{c}0.05 \mathrm{M} \mathrm{Na}_{2} \mathrm{SO}_{4} \\
\text { pH: } 3 \\
\text { AFR: } 0.6 \mathrm{~L} / \mathrm{min} \\
\mathrm{I}=125 \mathrm{~mA}\end{array}$ & $\begin{array}{l}6 \mathrm{~W} \text { UVA } \\
\text { fluorescent }\end{array}$ & $\begin{array}{l}100 \% \text { removal } \\
\text { (15 min) } \\
92 \% \text { TOC decay } \\
\text { (300 min) }\end{array}$ & [16] \\
\hline $\begin{array}{l}\text { Bezafibrate } \\
(10 \mathrm{mg} / \mathrm{L})\end{array}$ & $\begin{array}{l}\text { Fe-MOFs } \\
(0.05 \mathrm{~g} / \mathrm{L})\end{array}$ & $\begin{array}{l}\mathrm{IrO}_{2} / \text { air } \\
\text { diffusion } \\
\text { cathode }\end{array}$ & $\begin{array}{c}0.05 \mathrm{M} \mathrm{Na}_{2} \mathrm{SO}_{4} \\
\text { pH: } 5.1 \\
\text { AFR: } 1 \mathrm{~L} / \mathrm{min} \\
\mathrm{I}=100 \mathrm{~mA}\end{array}$ & $\begin{array}{c}150 \mathrm{~W} \\
\text { Xe lamp } \\
(\lambda>400 \mathrm{~nm})\end{array}$ & $\begin{array}{l}\text { 92\% removal } \\
\text { (90 min) } \\
61 \% \text { TOC decay } \\
\text { (240 min) }\end{array}$ & [48] \\
\hline $\begin{array}{l}\text { Thiamphenicol } \\
\text { (50 mg/L) }\end{array}$ & $\begin{array}{l}\text { Pyrite } \\
(2 \mathrm{~g} / \mathrm{L})\end{array}$ & $\begin{array}{l}\mathrm{IrO}_{2} / \text { air } \\
\text { diffusion } \\
\text { cathode }\end{array}$ & $\begin{array}{c}0.02 \mathrm{M} \mathrm{Na}_{2} \mathrm{SO}_{4} \\
\mathrm{pH}: 3.95 \\
\text { AFR: } 1 \mathrm{~L} / \mathrm{min} \\
\mathrm{I}=100 \mathrm{~mA}\end{array}$ & $\begin{array}{l}6 \mathrm{~W} \text { UVA } \\
\text { fluorescent }\end{array}$ & $\begin{array}{l}100 \% \text { removal } \\
\text { (60 min) } \\
85 \% \text { TOC decay } \\
\text { (360 min) }\end{array}$ & [81] \\
\hline
\end{tabular}




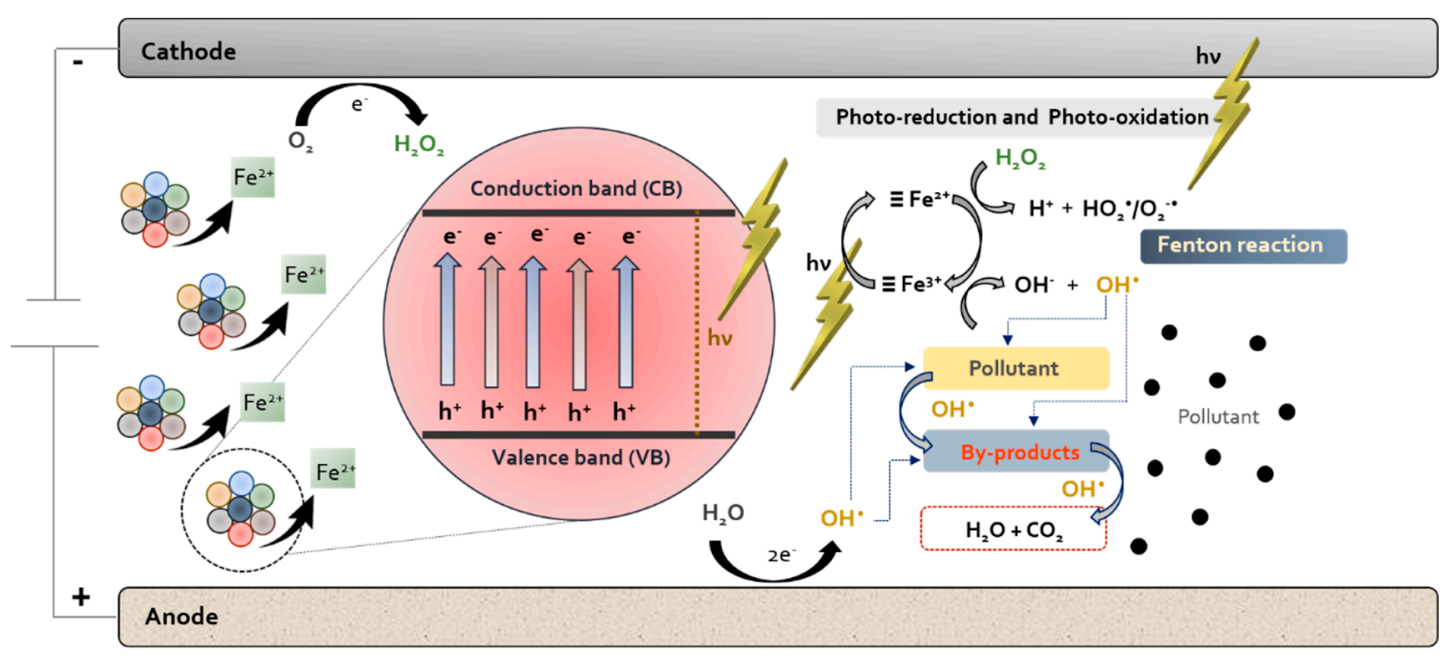

Figure 3. Mechanism of heterogeneous photoelectro-Fenton process.

When absorbed, the energy of the photons can be used to photo-reduce $[\mathrm{Fe}(\mathrm{OH})]^{2+}$ under acidic conditions (Equation (32)) and/or drive photodecarboxylation producing ferrous iron (Equation (33)) [48]:

$$
\begin{gathered}
{[\mathrm{Fe}(\mathrm{OH})]^{2+}+\mathrm{h} v \rightarrow \mathrm{Fe}^{2+}+{ }^{\bullet} \mathrm{OH}} \\
\mathrm{Fe}(\mathrm{OOCR})^{2+}+\mathrm{h} v \rightarrow \mathrm{Fe}^{2+}+\mathrm{CO}_{2}+\mathrm{R}^{\bullet}
\end{gathered}
$$

The majority of research into PEF has been carried out under acidic conditions, with only a small number of studies investigating the potential application at circumneutral $\mathrm{pH}$. Ye et al. [48] described the performance of an Fe-based 2D metal-organic framework (MOF) catalyst for the removal of bezafibrate in sulphate-based medium at $\mathrm{pH} 5.5$ using a single-compartment glass cell upon Xe lamp irradiation, reporting $92 \%$ removal-an increase in removal vs. the control experiments. UV photons have been shown to play a key role enhancing charge transfer and promoting Fe (III)/Fe (II) cycling. Studies in urban wastewater spiked with a range of emerging pollutants, bezafibrate, bisphenol A, fluoxetine and naproxen, and at neutral $\mathrm{pH}$ showed good removal efficiencies with 93, 85 and $78 \%$ removal reported for naproxen, fluoxetine and bisphenol A, respectively, after 90 min treatment. The authors concluded that the presence of organic matter, the high turbidity and the higher initial $\mathrm{pH}$ all play a role to reduce bezafibrate treatment.

Thiam et al. [81] analysed thiamphenicol degradation using photoelectro-Fenton process driven with UVA light and pyrite particles as the catalyst source. The regulatory role pyrite plays regarding solution acidification (according to the Equations (26)-(28)) was described to be significant, resulting in enhanced hydroxyl radicals generated via the photo-Fenton reaction. Under optimal conditions, more than $85 \%$ TOC decay was achieved after $360 \mathrm{~min}$ treatment, noted to be around a three-fold increase in comparison to the electro-Fenton process.

\section{Conclusions and Future Perspectives}

This review describes the present trends in the use of heterogenous catalysts for the removal of pharmaceuticals from aquatic environments, discussing the critical role of the parameters driving the electro-Fenton process. Although progress has been made with nano-engineered catalysts, high operating costs related to energy consumption, relatively slow degradation processes, and issues with reactor scale-up and catalyst re-use remain major challenges for this emerging field of research. Future studies should be focused on minimising energy consumption, through more efficient electrochemistry, or coupling with renewable energy generation sources such as photovoltaic panels, which can be easily scaled for industrial applications. The identification of efficient process parameters to 
deliver treated waters with high parent compound degradation does not always ensure effluent safety, however, mineralisation is not always required-careful attention should be paid to reducing the toxicity levels of treated water, and/or enhancing bio-availability via pre-treatment before wastewater treatment through biological process.

To date, academic research has focused on the initial developments of novel innovative wastewater treatment technologies for the removal of pharmaceuticals from simulated water under batch conditions. However, there is a need to assess efficacy in real water matrices where the presence of natural organic matter (humic and fulvic acids) will undoubtedly scavenge radical species reducing the effective degradation rate. The implementation of heterogeneous-based Fenton process as continuous flow systems is required to ensure potential for scale-up to real water treatment applications.

Significant efforts have been devoted to producing novel solid iron catalysts or ironfunctionalised cathodic materials, but more work is needed to evaluate these materials at circumneutral $\mathrm{pH}$ in order to ensure higher stability whilst maintaining ability to catalyse Fenton's reaction forming hydroxyl radicals. One area of significant promise is the integration of the electro-Fenton process with conventional technologies, and/or Fenton-based processes and indeed other AOP's, with significant improvements in mineralisation percentages observed. This topic remains a vibrant area for research and through the identification of niche applications could quickly transition to pilots and commercial exploitation.

Author Contributions: J.M.: conceptualisation, investigation, writing-original draft, writingreview-editing. P.S.M.D.: writing—review and editing. M.P.: funding acquisitions, writing-reviewediting. M.A.S.: funding acquisitions, writing-review and editing. All authors have read and agreed to the published version of the manuscript.

Funding: This research has been financially supported by the Spanish Ministry of Science, Innovation and Universities and ERDF (Grant N ${ }^{\circ}$ CTM2017-87326-R). The authors are grateful to the Xunta de Galicia for the financial support of Jessica Meijide under her postdoctoral fellowship (ED481B 2018/096).

Institutional Review Board Statement: Not applicable.

Informed Consent Statement: Not applicable.

Data Availability Statement: Date is contained within the article.

Conflicts of Interest: The authors declare that do not have known any financial and personal relationships that could inappropriately influence/bias the work reported in this paper.

\section{References}

1. Amin, M.T.; Alazba, A.A.; Manzoor, U. A Review of Removal of Pollutants from Water/Wastewater Using Different Types of Nanomaterials. Adv. Mater. Sci. Eng. 2014. [CrossRef]

2. United Nations. Resolution A/70/L.1 Adopted by the General Assembly on 25 September 2015. Transforming Our World: The 2030 Agenda for Sustainable Development, 2020 (2015). Available online: https:/ /www.un.org/en/development/desa/ population/migration/generalassembly/docs/globalcompact/A_RES_70_1_E.pdf (accessed on 30 October 2020).

3. Geissen, V.; Mol, H.G.J.; Klumpp, E.; Umlauf, G.; Nadal, M.; Van Der Ploeg, M.; Van De Zee, S.E.; Ritsema, C.J. Emerging pollutants in the environment: A challenge for water resource management. Int. Soil Water Conserv. Res. 2015, 3, 57-65. [CrossRef]

4. Awfa, D.; Ateia, M.; Fujii, M.; Johnson, M.S.; Yoshimura, C. Photodegradation of pharmaceuticals and personal care products in water treatment using carbonaceous- $\mathrm{TiO}_{2}$ composites: A critical review of recent literature. Water Res. 2018, 142, 26-45. [CrossRef] [PubMed]

5. Hernández-Uresti, D.; Vázquez, A.; Sanchez-Martinez, D.; Obregón, S. Performance of the polymeric g- $\mathrm{C}_{3} \mathrm{~N}_{4}$ photocatalyst through the degradation of pharmaceutical pollutants under UV-vis irradiation. J. Photochem. Photobiol. A Chem. 2016, 324, 47-52. [CrossRef]

6. Jallouli, N.; Pastrana-Martínez, L.M.; Ribeiro, A.R.; Moreira, N.F.; Faria, J.L.; Hentati, O.; Silva, A.M.; Ksibi, M. Heterogeneous photocatalytic degradation of ibuprofen in ultrapure water, municipal and pharmaceutical industry wastewaters using a $\mathrm{TiO}_{2}$ /UV-LED system. Chem. Eng. J. 2018, 334, 976-984. [CrossRef]

7. Bradley, P.M.; Journey, C.A.; Button, D.T.; Carlisle, D.M.; Clark, J.M.; Mahler, B.J.; Nakagaki, N.; Qi, S.L.; Waite, I.R.; VanMetre, P.C. Metformin and Other Pharmaceuticals Widespread in Wadeable Streams of the Southeastern United States. Environ. Sci. Technol. Lett. 2016, 3, 243-249. [CrossRef] 
8. Bu, Q.; Cao, Y.; Yu, G.; He, X.; Zhang, H.; Sun, J.; Yun, M.; Cao, Z. Identifying targets of potential concern by a screening level ecological risk assessment of human use pharmaceuticals in China. Chemosphere 2020, 246, 125818. [CrossRef]

9. Alvarino, T.; Suarez, S.; Lema, J.; Omil, F. Understanding the sorption and biotransformation of organic micropollutants in innovative biological wastewater treatment technologies. Sci. Total Environ. 2018, 615, 297-306. [CrossRef]

10. Carballa, M.; Omil, F.; Lema, J.M.; Llompart, M.; García-Jares, C.; Rodríguez, I.; Gómez, M.; Ternes, T. Behavior of pharmaceuticals, cosmetics and hormones in a sewage treatment plant. Water Res. 2004, 38, 2918-2926. [CrossRef]

11. Zhu, Y.; Zhu, J.; Xi, Y.; Zhu, J.; Zhu, G.; He, H. Strategies for enhancing the heterogeneous Fenton catalytic reactivity: A review. Appl. Catal. B Environ. 2019, 255, 117739. [CrossRef]

12. Ganiyu, S.O.; Zhou, M.; Martínez-Huitle, C.A. Heterogeneous electro-Fenton and photoelectro-Fenton processes: A critical review of fundamental principles and application for water/wastewater treatment. Appl. Catal. B Environ. 2018, 235, 103-129. [CrossRef]

13. Yang, W.; Zhou, M.; Oturan, N.; Bechelany, M.; Cretin, M.; Oturan, M.A. Highly efficient and stable Fe ${ }^{\mathrm{II}} \mathrm{Fe}^{\mathrm{III}} \mathrm{LDH}$ carbon felt cathode for removal of pharmaceutical ofloxacin at neutral pH. J. Hazard. Mater. 2020, 393, 122513. [CrossRef] [PubMed]

14. Tian, Y.; Zhou, M.; Pan, Y.; Du, X.; Wang, Q. $\mathrm{MoS}_{2}$ as highly efficient co-catalyst enhancing the performance of Fe ${ }^{0}$ based electro-Fenton process in degradation of sulfamethazine: Approach and mechanism. Chem. Eng. J. 2021, 403, 126361. [CrossRef]

15. Ghasemi, M.; Khataee, A.; Gholami, P.; Soltani, R.D.C. Template-free microspheres decorated with Cu-Fe-NLDH for catalytic removal of gentamicin in heterogeneous electro-Fenton process. J. Environ. Manag. 2019, 248, 109236. [CrossRef] [PubMed]

16. Droguett, C.; Salazar, R.; Brillas, E.; Sirés, I.; Carlesi, C.; Marco, J.F.; Thiam, A. Treatment of antibiotic cephalexin by heterogeneous electrochemical Fenton-based processes using chalcopyrite as sustainable catalyst. Sci. Total Environ. 2020, 740, 140154. [CrossRef] [PubMed]

17. Barhoumi, N.; Olvera-Vargas, H.; Oturan, M.A.; Huguenot, D.; Gadri, A.; Ammar, S.; Brillas, E.; Oturan, M.A. Kinetics of oxidative degradation/mineralization pathways of the antibiotic tetracycline by the novel heterogeneous electro-Fenton process with solid catalyst chalcopyrite. Appl. Catal. B Environ. 2017, 209, 637-647. [CrossRef]

18. Monteil, H.; Péchaud, Y.; Oturan, N.; Oturan, M.A. A review on efficiency and cost effectiveness of electro- and bio-electro-Fenton processes: Application to the treatment of pharmaceutical pollutants in water. Chem. Eng. J. 2019, 376, 119577. [CrossRef]

19. Wang, Y.; Zhao, G.; Chai, S.; Zhao, H.; Wang, Y. Three-Dimensional Homogeneous Ferrite-Carbon Aerogel: One Pot Fabrication and Enhanced Electro-Fenton Reactivity. ACS Appl. Mater. Interfaces 2013, 5, 842-852. [CrossRef]

20. Luo, T.; Feng, H.; Tang, L.; Lu, Y.; Tang, W.; Chen, S.; Yu, J.; Xie, Q.; Ouyang, X.; Chen, Z. Efficient degradation of tetracycline by heterogeneous electro-Fenton process using $\mathrm{Cu}$-doped $\mathrm{Fe}_{\mathrm{F}} \mathrm{Fe}_{2} \mathrm{O}_{3}$ : Mechanism and degradation pathway. Chem. Eng. J. 2020, 382, 122970. [CrossRef]

21. Segura, S.G.; Brillas, E. Mineralization of the recalcitrant oxalic and oxamic acids by electrochemical advanced oxidation processes using a boron-doped diamond anode. Water Res. 2011, 45, 2975-2984. [CrossRef]

22. Meijide, J.; Pazos, M.; Sanromán, M. Heterogeneous electro-Fenton catalyst for 1-butylpyridinium chloride degradation. Environ. Sci. Pollut. Res. 2017, 26, 3145-3156. [CrossRef] [PubMed]

23. Bounab, L.; Iglesias, O.; González-Romero, E.; Pazos, M.; Sanromán, M. Effective heterogeneous electro-Fenton process of m-cresol with iron loaded actived carbon. RSC Adv. 2015, 5, 31049-31056. [CrossRef]

24. Vilar, V.J.; Moreira, F.C.; Ferreira, A.C.; Sousa, M.; Gonçalves, C.; Alpendurada, M.; Boaventura, R.A. Biodegradability enhancement of a pesticide-containing bio-treated wastewater using a solar photo-Fenton treatment step followed by a biological oxidation process. Water Res. 2012, 46, 4599-4613. [CrossRef] [PubMed]

25. Meijide, J.; Rodríguez, S.; Sanromán, M.A.; Pazos, M. Comprehensive solution for acetamiprid degradation: Combined electroFenton and adsorption process. J. Electroanal. Chem. 2018, 808, 446-454. [CrossRef]

26. Poza-Nogueiras, V.; Rosales, E.; Pazos, M.; Sanromán, M. Current advances and trends in electro-Fenton process using heterogeneous catalysts-A review. Chemosphere 2018, 201, 399-416. [CrossRef] [PubMed]

27. Barhoumi, N.; Oturan, N.; Ammar, S.; Gadri, A.; Oturan, M.A.; Brillas, E. Enhanced degradation of the antibiotic tetracycline by heterogeneous electro-Fenton with pyrite catalysis. Environ. Chem. Lett. 2017, 15, 689-693. [CrossRef]

28. Kumar, A.; Rana, A.; Sharma, G.; Naushad, M.; Dhiman, P.; Kumari, A.; Stadler, F.J. Recent advances in nano-Fenton catalytic degradation of emerging pharmaceutical contaminants. J. Mol. Liq. 2019, 290, 111177. [CrossRef]

29. Campos, S.; Salazar, R.; Arancibia-Miranda, N.; Rubio, M.; Aranda, M.; García, A.; Sepúlveda, P.; Espinoza, L.C. Nafcillin degradation by heterogeneous electro-Fenton process using $\mathrm{Fe}, \mathrm{Cu}$ and $\mathrm{Fe} / \mathrm{Cu}$ nanoparticles. Chemosphere 2020, $247,125813$. [CrossRef]

30. Carrasco-Díaz, M.R.; Castillejos-López, E.; Cerpa-Naranjo, A.; Rojas-Cervantes, M.L. Efficient removal of paracetamol using $\mathrm{LaCu}_{1-\mathrm{x}} \mathrm{M}_{\mathrm{x}} \mathrm{O}_{3}(\mathrm{M}=\mathrm{Mn}, \mathrm{Ti})$ perovskites as heterogeneous Fenton-like catalysts. Chem. Eng. J. 2016, 304, 408-418. [CrossRef]

31. Özcan, A.; Özcan, A.A.; Demirci, Y.; Şener, E. Preparation of $\mathrm{Fe}_{2} \mathrm{O}_{3}$ modified kaolin and application in heterogeneous electrocatalytic oxidation of enoxacin. Appl. Catal. B Environ. 2017, 200, 361-371. [CrossRef]

32. Puga, A.; Rosales, E.; Pazos, M.; Sanromán, M. Prompt removal of antibiotic by adsorption/electro-Fenton degradation using an iron-doped perlite as heterogeneous catalyst. Process. Saf. Environ. Prot. 2020, 144, 100-110. [CrossRef]

33. Du, X.; Fu, W.; Su, P.; Cai, J.; Zhou, M. Internal-micro-electrolysis-enhanced heterogeneous electro-Fenton process catalyzed by $\mathrm{Fe} / \mathrm{Fe}_{3} \mathrm{C} @ \mathrm{PC}$ core-shell hybrid for sulfamethazine degradation. Chem. Eng. J. 2020, 398, 125681. [CrossRef]

34. Divyapriya, G.; Nidheesh, P. Importance of Graphene in the Electro-Fenton Process. ACS Omega 2020, 5, 4725-4732. [CrossRef] [PubMed] 
35. Mohammadi, H.; Bina, B.; Ebrahimi, A. A novel three-dimensional electro-Fenton system and its application for degradation of anti-inflammatory pharmaceuticals: Modeling and degradation pathways. Process. Saf. Environ. Prot. 2018, 117, $200-213$. [CrossRef]

36. Mi, X.; Li, Y.; Ning, X.; Jia, J.; Wang, H.; Xia, Y.; Sun, Y.; Zhan, S. Electro-Fenton degradation of ciprofloxacin with highly ordered mesoporous MnCo2O4-CF cathode: Enhanced redox capacity and accelerated electron transfer. Chem. Eng. J. 2019, 358, 299-309. [CrossRef]

37. Ganiyu, S.O.; Le, T.X.H.; Bechelany, M.; Oturan, M.A.; Papirio, S.; Esposito, G.; Van Hullebusch, E.; Cretin, M.; Oturan, M.A. Electrochemical mineralization of sulfamethoxazole over wide $\mathrm{pH}$ range using $\mathrm{Fe}^{\mathrm{II}} \mathrm{Fe}{ }^{\mathrm{III}} \mathrm{LDH}$ modified carbon felt cathode: Degradation pathway, toxicity and reusability of the modified cathode. Chem. Eng. J. 2018, 350, 844-855. [CrossRef]

38. Nsubuga, H.; Basheer, C.; Haider, M.B. An enhanced beta-blockers degradation method using copper-boron-ferrite supported graphite electrodes and continuous droplet flow-assisted electro-Fenton reactor. Sep. Purif. Technol. 2019, 221, 408-420. [CrossRef]

39. Pourzamani, H.; Hajizadeh, Y.; Mengelizadeh, N. Application of three-dimensional electrofenton process using $\mathrm{MWCNTs}^{-F_{3} \mathrm{O}_{4}}$ nanocomposite for removal of diclofenac. Process. Saf. Environ. Prot. 2018, 119, 271-284. [CrossRef]

40. Barhoumi, N.; Oturan, M.A.; Olvera-Vargas, H.; Brillas, E.; Gadri, A.; Ammar, S.; Oturan, M.A. Pyrite as a sustainable catalyst in electro-Fenton process for improving oxidation of sulfamethazine. Kinetics, mechanism and toxicity assessment. Water Res. 2016, 94, 52-61. [CrossRef]

41. Rahmatinia, Z.; Rahmatinia, M. Removal of the metronidazole from aqueous solution by heterogeneous electro-Fenton process using nano- $\mathrm{Fe}_{3} \mathrm{O}_{4}$. Data Brief. 2018, 19, 2139-2145. [CrossRef]

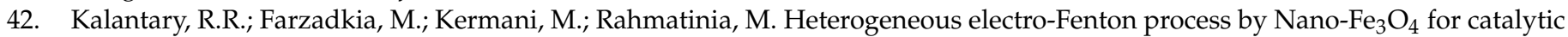
degradation of amoxicillin: Process optimization using response surface methodology. J. Environ. Chem. Eng. 2018, 6, 4644-4652. [CrossRef]

43. Rosales, E.; Diaz, S.; Pazos, M.; Sanromán, M.A. Comprehensive strategy for the degradation of anti-inflammatory drug diclofenac by different advanced oxidation processes. Sep. Purif. Technol. 2019, 208, 130-141. [CrossRef]

44. Sadeghi, M.; Mehdinejad, M.H.; Mengelizadeh, N.; Mahdavi, Y.; Pourzamani, H.; Hajizadeh, Y.; Zare, M.R. Degradation of diclofenac by heterogeneous electro-Fenton process using magnetic single-walled carbon nanotubes as a catalyst. J. Water Process. Eng. 2019, 31, 100852. [CrossRef]

45. Görmez, F.; Görmez, Ö.; Gözmen, B.; Kalderis, D. Degradation of chloramphenicol and metronidazole by electro-Fenton process using graphene oxide-Fe3O4 as heterogeneous catalyst. J. Environ. Chem. Eng. 2019, 7, 102990. [CrossRef]

46. Nsubuga, H.; Basheer, C.; Jalilov, A.; Haider, M.B.; Al-Saadi, A.A. Droplet flow-assisted heterogeneous electro-Fenton reactor for degradation of beta-blockers: Response surface optimization, and mechanism elucidation. Environ. Sci. Pollut. Res. 2019, 26, 14313-14327. [CrossRef]

47. Yu, F.; Wang, Y.; Ma, H.; Zhou, M. Hydrothermal synthesis of $\mathrm{FeS}_{2}$ as a highly efficient heterogeneous electro-Fenton catalyst to degrade diclofenac via molecular oxygen effects for Fe(II)/Fe(III) cycle. Sep. Purif. Technol. 2020, 248, 117022. [CrossRef]

48. Ye, Z.; Schukraft, G.E.; L'Hermitte, A.; Xiong, Y.; Brillas, E.; Petit, C.; Sirés, I. Mechanism and stability of an Fe-based 2D MOF during the photoelectro-Fenton treatment of organic micropollutants under UVA and visible light irradiation. Water Res. 2020, 184, 115986. [CrossRef]

49. Liu, D.; Zhang, H.; Wei, Y.-Q.; Liu, B.; Lin, Y.; Li, G.; Zhang, F. Enhanced degradation of ibuprofen by heterogeneous electro-Fenton at circumneutral $\mathrm{pH}$. Chemosphere 2018, 209, 998-1006. [CrossRef]

50. Sun, Y.; Li, Y.; Mi, X.; Zhan, S.; Hu, W. Evaluation of ciprofloxacin destruction between ordered mesoporous and bulk $\mathrm{NiMn}_{2} \mathrm{O}_{4}$ /CF cathode: Efficient mineralization in a heterogeneous electro-Fenton-like process. Environ. Sci. Nano 2019, 6, 661-671. [CrossRef]

51. Ghasemi, M.; Khataee, A.; Gholami, P.; Soltani, R.D.C.; Hassani, A.; Orooji, Y. In-situ electro-generation and activation of hydrogen peroxide using a CuFeNLDH-CNTs modified graphite cathode for degradation of cefazolin. J. Environ. Manag. 2020, 267, 110629. [CrossRef]

52. Johansson, C.H.; Janmar, L.; Backhaus, T. Toxicity of ciprofloxacin and sulfamethoxazole to marine periphytic algae and bacteria. Aquat. Toxicol. 2014, 156, 248-258. [CrossRef] [PubMed]

53. Xiong, W.; Zeng, Z.; Li, X.; Niu, C.-G.; Xiao, R.; Yang, Z.; Zhou, Y.; Zhang, C.; Cheng, M.; Hu, L.; et al. Multi-walled carbon nanotube/amino-functionalized MIL-53(Fe) composites: Remarkable adsorptive removal of antibiotics from aqueous solutions. Chemosphere 2018, 210, 1061-1069. [CrossRef] [PubMed]

54. Zhang, C.; Lai, C.; Zeng, G.; Huang, D.; Yang, C.; Wang, Y.; Zhou, Y.; Cheng, M. Efficacy of carbonaceous nanocomposites for sorbing ionizable antibiotic sulfamethazine from aqueous solution. Water Res. 2016, 95, 103-112. [CrossRef] [PubMed]

55. Fan, Y.; Ji, Y.; Kong, D.; Lu, J.; Zhou, Q. Kinetic and mechanistic investigations of the degradation of sulfamethazine in heat-activated persulfate oxidation process. J. Hazard. Mater. 2015, 300, 39-47. [CrossRef] [PubMed]

56. Thiam, A.; Brillas, E.; Garrido, J.A.; Rodríguez, R.M.; Sirés, I. Routes for the electrochemical degradation of the artificial food azo-colour Ponceau $4 \mathrm{R}$ by advanced oxidation processes. Appl. Catal. B Environ. 2016, 180, 227-236. [CrossRef]

57. Benito-Peña, E.; Partal-Rodera, A.; León-González, M.; Bondi, M.C. Evaluation of mixed mode solid phase extraction cartridges for the preconcentration of beta-lactam antibiotics in wastewater using liquid chromatography with UV-DAD detection. Anal. Chim. Acta 2006, 556, 415-422. [CrossRef] 
58. Elmolla, E.S.; Chaudhuri, M. Optimization of Fenton process for treatment of amoxicillin, ampicillin and cloxacillin antibiotics in aqueous solution. J. Hazard. Mater. 2009, 170, 666-672. [CrossRef] [PubMed]

59. Elmolla, E.S.; Chaudhuri, M. Degradation of the antibiotics amoxicillin, ampicillin and cloxacillin in aqueous solution by the photo-Fenton process. J. Hazard. Mater. 2009, 172, 1476-1481. [CrossRef]

60. Panizza, M.; Dirany, A.; Sirés, I.; Haidar, M.; Oturan, N.; Oturan, M.A. Complete mineralization of the antibiotic amoxicillin by electro-Fenton with a BDD anode. J. Appl. Electrochem. 2014, 44, 1327-1335. [CrossRef]

61. Berendsen, B.; Stolker, L.; De Jong, J.; Nielen, M.; Tserendorj, E.; Sodnomdarjaa, R.; Cannavan, A.; Elliott, C. Evidence of natural occurrence of the banned antibiotic chloramphenicol in herbs and grass. Anal. Bioanal. Chem. 2010, 397, 1955-1963. [CrossRef]

62. Zuorro, A.; Fidaleo, M.; Fidaleo, M.; Lavecchia, R. Degradation and antibiotic activity reduction of chloramphenicol in aqueous solution by UV/H2O2 process. J. Environ. Manag. 2014, 133, 302-308. [CrossRef] [PubMed]

63. Nie, M.; Yan, C.; Li, M.; Wang, X.; Bi, W.; Dong, W. Degradation of chloramphenicol by persulfate activated by Fe $\mathrm{Fe}^{2+}$ and zerovalent iron. Chem. Eng. J. 2015, 279, 507-515. [CrossRef]

64. Ahmed, M.J.; Theydan, S.K. Microwave assisted preparation of microporous activated carbon from Siris seed pods for adsorption of metronidazole antibiotic. Chem. Eng. J. 2013, 214, 310-318. [CrossRef]

65. Seo, P.W.; Khan, N.A.; Jhung, S.H. Removal of nitroimidazole antibiotics from water by adsorption over metal-organic frameworks modified with urea or melamine. Chem. Eng. J. 2017, 315, 92-100. [CrossRef]

66. Khetan, S.K.; Collins, T.J. Human Pharmaceuticals in the Aquatic Environment: A Challenge to Green Chemistry. Chem. Rev. 2007, 107, 2319-2364. [CrossRef] [PubMed]

67. Amendola, L.; Molaioni, F.; Botrè, F. Detection of beta-blockers in human urine by GC-MS-MS-EI: Perspectives for the antidoping control. J. Pharm. Biomed. Anal. 2000, 23, 211-221. [CrossRef]

68. Ganiyu, S.O.; Oturan, M.A.; Raffy, S.; Esposito, G.; Van Hullebusch, E.D.; Cretin, M.; Oturan, M.A. Use of Sub-stoichiometric Titanium Oxide as a Ceramic Electrode in Anodic Oxidation and Electro-Fenton Degradation of the Beta-blocker Propranolol: Degradation Kinetics and Mineralization Pathway. Electrochim. Acta 2017, 242, 344-354. [CrossRef]

69. Ramil, M.; El Aref, T.; Fink, G.; Scheurer, M.; Ternes, T.A. Fate of Beta Blockers in Aquatic-Sediment Systems: Sorption and Biotransformation. Environ. Sci. Technol. 2010, 44, 962-970. [CrossRef]

70. Wang, L.; Xu, H.; Cooper, W.J.; Song, W. Photochemical fate of beta-blockers in NOM enriched waters. Sci. Total Environ. 2012, 426, 289-295. [CrossRef]

71. Rigobello, E.S.; Dantas, A.D.B.; Di Bernardo, L.; Vieira, E.M. Removal of diclofenac by conventional drinking water treatment processes and granular activated carbon filtration. Chemosphere 2013, 92, 184-191. [CrossRef]

72. Fent, K.; Weston, A.A.; Caminada, D. Ecotoxicology of human pharmaceuticals. Aquat. Toxicol. 2006, 76, 122-159. [CrossRef] [PubMed]

73. Ali, I.; Singh, P.; Aboul-Enein, H.Y.; Sharma, B. Chiral Analysis of Ibuprofen Residues in Water and Sediment. Anal. Lett. 2009, 42, 1747-1760. [CrossRef]

74. Lonappan, L.; Brar, S.K.; Das, R.K.; Verma, M.; Surampalli, R.Y. Diclofenac and its transformation products: Environmental occurrence and toxicity-A review. Environ. Int. 2016, 96, 127-138. [CrossRef] [PubMed]

75. Zhang, Y.; Geissen, S.-U.; Gal, C. Carbamazepine and diclofenac: Removal in wastewater treatment plants and occurrence in water bodies. Chemosphere 2008, 73, 1151-1161. [CrossRef]

76. Barbosa, M.O.; Moreira, N.F.; Ribeiro, A.R.; Pereira, M.F.; Silva, A.M.T. Occurrence and removal of organic micropollutants: An overview of the watch list of EU Decision 2015/495. Water Res. 2016, 94, 257-279. [CrossRef]

77. Cho, H.-H.; Huang, H.; Schwab, K. Effects of Solution Chemistry on the Adsorption of Ibuprofen and Triclosan onto Carbon Nanotubes. Langmuir 2011, 27, 12960-12967. [CrossRef]

78. Ahmed, M.J. Adsorption of non-steroidal anti-inflammatory drugs from aqueous solution using activated carbons: Review. J. Environ. Manag. 2017, 190, 274-282. [CrossRef]

79. Vecitis, C.D.; Gao, G.; Liu, H. Electrochemical Carbon Nanotube Filter for Adsorption, Desorption, and Oxidation of Aqueous Dyes and Anions. J. Phys. Chem. C 2011, 115, 3621-3629. [CrossRef]

80. Brillas, E. A review on the photoelectro-Fenton process as efficient electrochemical advanced oxidation for wastewater remediation. Treatment with UV light, sunlight, and coupling with conventional and other photo-assisted advanced technologies. Chemosphere 2020, 250, 126198. [CrossRef]

81. Thiam, A.; Salazar, R.; Brillas, E.; Sirés, I. In-situ dosage of $\mathrm{Fe}^{2+}$ catalyst using natural pyrite for thiamphenicol mineralization by photoelectro-Fenton process. J. Environ. Manag. 2020, 270, 110835. [CrossRef] 